DIW BERLIN

Discussion

Papers

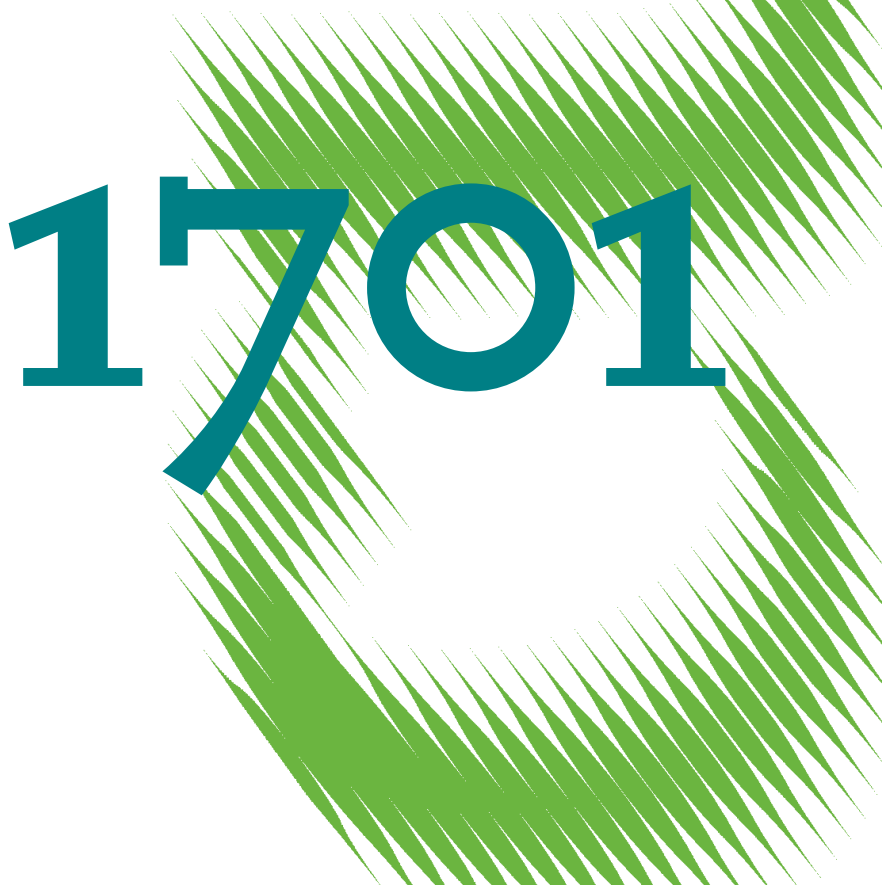

US Monetary Policy and the Euro Area 
Opinions expressed in this paper are those of the author(s) and do not necessarily reflect views of the institute.

IMPRESSUM

(C) DIW Berlin, 2017

DIW Berlin

German Institute for Economic Research

Mohrenstr. 58

10117 Berlin

Tel. +49 (30) $89789-0$

Fax +49 (30) $89789-200$

http://www.diw.de

ISSN electronic edition 1619-4535

Papers can be downloaded free of charge from the DIW Berlin website:

http://www.diw.de/discussionpapers

Discussion Papers of DIW Berlin are indexed in RePEc and SSRN:

http://ideas.repec.org/s/diw/diwwpp.html

http://www.ssrn.com/link/DIW-Berlin-German-Inst-Econ-Res.html 


\title{
US Monetary Policy and the Euro Area
}

\author{
Max Hanisch* \\ June 2018 \\ Revised version
}

\begin{abstract}
This study documents empirically that contractionary US monetary policy may generate short-term expansionary spillover effects. In individual Euro Area (EA) member countries, economic activity increases, mainly via the trade channel. Also, domestic credit and stock markets expand, highlighting the importance of the financial channel. However, the international repercussions are transitory and distributed unevenly within the EA. The effect diminishes as EA interest rates increase with a few quarters delay. While the effects are heterogenous and rather large before 1999, responses become more homogeneous and smaller in size after the implementation of the euro. Still, country-specific asymmetries remain.
\end{abstract}

JEL Classification: C32, E52, E58

Keywords: Structural dynamic factor model; Sign restrictions; Monetary policy; US; Euro Area; Spillover effects

*DIW Berlin, Mohrenstr. 58, 10117 Berlin, Germany, Phone: +49 30 89789-409, Email: mhanisch@diw.de.

Institute of International Economics, University of Muenster, Universitaetsstr. 14-16, 48143 Muenster, Germany. 


\section{Introduction}

This study documents that contractionary US monetary policy may generate short-term expansionary international spillover effects. Cross-country repercussions of a US monetary tightening stimulate economic activity in the Euro Area (EA). This is mainly due to the depreciation of the euro and increasing EA net exports. In the short term, the positive trade effect thus dominates the negative income effect that follows from a slowdown in US economic activity. However, the strength of the responses varies in individual EA member countries. Moreover, EA responses to the US shock also vary across time. The analysis runs from 1983 through 2015 and thus also covers the period prior to the introduction of the euro in 1999. A-priori it is not evident whether and to what extent the implementation of the euro has affected the individual member countries' resilience towards a foreign monetary shock. I find the responses to become smaller and more homogenous after 1999, although country-specific asymmetries persist. The uneven distribution of the responses emphasizes the importance of analyzing the international effects of US monetary policy in detail, both in the cross section and the time dimension.

Based on a structural dynamic factor model that exploits a high-dimensional data set, the paper thus contributes to the literature as it applies an econometric framework that overcomes two main methodological obstacles. First, Georgiadis (2016) shows that international spillovers heavily depend on individual country characteristics such as trade, financial integration or labor market rigidities. These characteristics are different from country to country and it is crucial to take them into account in order to properly quantify the impact of the foreign shock. In the dynamic factor model, the EA member countries Germany, France, the Netherlands, Italy and Spain are modelled individually based on 
a large-scale data set that comprises about 30 key economic indicators per country. The results reveal substantial heterogeneity within the group of EA member states. The approach chosen here thus seriously reduces the chance to miss out on important individual country characteristics.

Second, Georgiadis (2017) demonstrates that higher-order spillovers and spillbacks have to be controlled for in order to achieve unbiased estimates of international cross-country effects. Given their close economic and political ties, these feedback effects are surely present within the group of EA countries. In order to explicitly account for the dynamic intra-EA interaction, the approach chosen here models all EA countries jointly. Furthermore, estimating both the shock and the individual spillover effects in a single econometric framework makes the results directly comparable across countries. This should lead to unbiased estimates of the effects of the US monetary shock and more comprehensively capture its cross-border transmission as compared to the standard approaches employed so far (discussed below).

The paper offers the following, previously undetected, insights onto the cross-country effects and the relevant transmission channels of US policy decisions. First, multilateral spillover effects of contractionary US monetary policy on economic activity and financial markets in individual EA member countries are asymmetric. Output, private consumption and investment increase especially in Germany but also in France and the Netherlands and remain subdued in Italy and Spain. This somewhat surprising effect mainly works through the trade channel as exchange rates depreciate and net exports rise. Domestic credit, stock markets and house prices initially increase. However, the economic expansion is rather short-lived as EA short and long-term interest rates increase through the financial channel 
with a few quarters delay. Thus, simultaneously controlling for a variety of transmission channels and higher-order spillovers and spillbacks I document a short-lived economic expansion in the EA that is distributed unevenly between individual countries. This is an effect undetected so far due to the reliance of previous studies on EA aggregates or two-country bilateral models. Second, I uncover substantial heterogeneity among the responses not only across countries but also across time. While the impact of the foreign shock varies in strength and is rather large before the introduction of the euro in 1999, a statistically significant convergence process towards more homogenous and overall smaller responses is found after the implementation of the single currency. Thus, US monetary policy has a sizeable impact on EA economic and financial stability. However, the results suggest that forming a currency union where all countries share the same exchange rate against the US dollar may reduce its cross-border impact.

Interestingly, the previous literature on spillover effects of US monetary policy is far from conclusive regarding even the basic direction of its international impact. While the effects are frequently reported to be symmetric, i.e. a recession in the US spreads globally (Kim, 1999; Georgiadis, 2016; Banerjee et al., 2016), several studies document mixed effects (Maćkowiak, 2007; Bluedorn, Bowdler, 2011; Dedola et al., 2017). Contrarily, some studies suggest the shock to have expansionary effects abroad (Canova, 2005; Neri and Nobili, 2010). The latter two studies are based on aggregates of Latin American and EA countries, respectively, and do not allow for country-specific responses (which may be different from the average response). Furthermore, the transmission channels through which the shock proliferates and the relative strength of these mechanisms are discussed controversially. Typically, symmetric effects are found to spread through increasing global 
interest rates. Studies that document asymmetric effects highlight more the importance of the trade channel (Bernanke, 2017).

A source for the lack of consensus in the literature is the large variety of empirical approaches and the use of aggregates instead of modeling countries individually. While Kim (1999), Maćkowiak (2007) and Bluedorn and Bowdler (2011) employ small-scale bilateral VAR models, Canova (2005), Neri and Nobili (2010) and Banerjee et al. (2016) work with country groups that aggregate advanced or emerging economies in different compositions. Georgiadis (2016) estimates a larger-scale global VAR (GVAR) that enlarges the number of countries under consideration but remains limited regarding the number of variables on the country level. Dedola et al. (2017) attempt to overcome this issue by first estimating the monetary policy shock in a medium-scale US VAR model. In a second step, thirdcountry variables are regressed one by one on the shock. While this approach expands the number of indicators under consideration, it does not control for the contemporaneous interactions between all recipients of the shock as each variable enters the model one by one. The variety of empirical models chosen to pin down the cross-country impact of US monetary policy and their individual methodological issues thus impede a clear-cut conclusion even regarding the basic direction of its effect on international economic activity. In order to overcome these impairments I draw on a structural dynamic factor model that heavily benefits from the merits discussed above. Indeed, I uncover previously undocumented heterogeneity. The effects of the US policy shock are country-specific and time dependent.

The remainder of the paper is organized as follows. Section 2 presents the model and the identification strategy. Section 3 discusses the data and the model setup. Results are 
presented in section 4 and robustness analyses in section 5. Section 6 concludes.

\section{A multi-country structural dynamic factor model}

\subsection{The model}

Introduced by Giannone et al. (2005), Stock and Watson (2005) and Forni et al. (2009), dynamic factor models have become a frequently employed approach to analyze the response of large data sets to macroeconomic shocks. While Forni and Gambetti (2010), Luciani (2015) and Hanisch (2017) investigate the effects of domestic monetary policy, Eickmeier (2007), Barigozzi et al. (2014) and Hanisch and Kempa (2017) set up multicountry models in order to analyze international spillover effects of such shocks.

The general idea is that the group of countries under consideration is driven by a few structural area-wide shocks and several regional or sectoral shocks. Each variable $x_{i t}$, where $i=1, \ldots, N$ is the number of variables and $t=1, \ldots, T$ is the sample length, is assumed to be the sum of two unobservable mutually orthogonal components:

$$
x_{i t}=\chi_{i t}+\xi_{i t},
$$

where $\chi_{i t}$ is the common component, assumed to affect the entire set of variables, and $\xi_{i t}$ is the idiosyncratic component, assumed to affect only certain groups of variables. Both $N$ and $T$ can be large, allowing for a comprehensive representation of the individual countries. The idiosyncratic component is allowed to be mildly cross-sectionally correlated. It can thus be thought of as source of regional business cycle fluctuations specific to one country or a sub-group of countries, leaving others mostly unaffected, or of sector-specific 
variations, e.g. shocks to financial markets or the housing sector.

The common component is assumed to be the main source of macroeconomic comovements in the data set, being a linear combination of $r \leq n$ static factors $f_{k t}$, $k=1, \ldots, r:$

$$
\chi_{i t}=a_{1 i} f_{1 t}+a_{2 i} f_{2 t}+\ldots+a_{k i} f_{k t}=\boldsymbol{a}_{\boldsymbol{i}} \boldsymbol{f}_{\boldsymbol{t}} .
$$

The static factors in the vector $\boldsymbol{f}_{\boldsymbol{t}}$ summarize the dynamics of the system. As such, it follows the VAR relation

$$
\boldsymbol{D}(L) \boldsymbol{f}_{t}=\varepsilon_{t},
$$

where $\boldsymbol{D}(L)$ is an $r \times r$ matrix lag polynomial and $\varepsilon_{\boldsymbol{t}}$ contains the VAR residuals. The static factors are driven by $q \leq r$ common shocks $u_{j t}, j=1, \ldots, q$. Thus, the variancecovariance matrix $\varepsilon_{t}$ can be decomposed into

$$
\varepsilon_{t}=R u_{t}
$$

where $\boldsymbol{R}$ is an $r \times q$ matrix. The common shocks in the $q$-dimensional vector $\boldsymbol{u}_{\boldsymbol{t}}=$ $\left(u_{1 t}, \ldots, u_{q t}\right)^{\prime}$ with $\boldsymbol{u}_{t} \sim \operatorname{iid}(\mathbf{0}, \boldsymbol{I})$ are the structural macroeconomic shocks that jointly drive the economies. Following Forni and Gambetti (2010), estimation is achieved in three steps. First, given an estimate $\hat{r}$, the static factors and the associated factor loadings in equation 2 are estimated by means of principal components. Second, a $\operatorname{VAR}(\hat{p})$ with $\hat{\boldsymbol{f}}_{\boldsymbol{t}}$ is run, as in equation 3, yielding estimates of $\boldsymbol{D}(L)$ and $\hat{\varepsilon_{t}}$. Third, given $\hat{q}$, estimates of $\hat{\boldsymbol{R}}$ and $\hat{\boldsymbol{u}}_{\boldsymbol{t}}$ from equation 4 are obtained by using the spectral decomposition of the variance-covariance matrix of $\hat{\varepsilon_{t}}$. 
From equation 1-4 the model can be rewritten as

$$
x_{i t}=b_{i 1} u_{1 t}+b_{i 2} u_{2 t}+\ldots+b_{i j} u_{j t}+\xi_{i t}=\boldsymbol{b}_{\boldsymbol{i}}(L) \boldsymbol{u}_{\boldsymbol{t}}+\xi_{i t},
$$

where

$$
\boldsymbol{b}_{\boldsymbol{i}}(L)=\boldsymbol{a}_{\boldsymbol{i}} \boldsymbol{D}(L)^{-1} \boldsymbol{R}
$$

contains the non-structural impulse responses. However, equation 6 only describes the space spanned by the static factors. The static factors themselves do not have a direct structural meaning but merely summarize the dynamics of the model. In order to introduce an economically meaningful structure to the model, additional restrictions are necessary. Thus, let $\boldsymbol{H}$ be a $q \times q$ rotation matrix that satisfies $\boldsymbol{H} \boldsymbol{H}^{\prime}=\boldsymbol{I}$. Then, $\boldsymbol{R} \boldsymbol{u}_{\boldsymbol{t}}=\boldsymbol{S} \boldsymbol{v}_{\boldsymbol{t}}$, where $\boldsymbol{S}=\boldsymbol{R} \boldsymbol{H}^{\prime}$ and $\boldsymbol{v}_{\boldsymbol{t}}=\boldsymbol{H} \boldsymbol{u}_{\boldsymbol{t}}$. This transformation yields the observationally equivalent model representation

$$
x_{i t}=\boldsymbol{c}_{\boldsymbol{i}}(L) \boldsymbol{v}_{\boldsymbol{t}}+\xi_{i t}
$$

where $\boldsymbol{c}_{\boldsymbol{i}}(L)=\boldsymbol{b}_{\boldsymbol{i}}(L) \boldsymbol{H}^{\prime}$ entails the structural impulse response functions. Sign restrictions imposed on the rotation matrix $\boldsymbol{H}$ allow for the unique identification of common shocks and impulse responses.

Following Barigozzi et al. (2014) and Luciani (2015), confidence intervals are built using a bootstrap algorithm, which, along the lines of Kilian (1998), corrects for possible distortions through the small-sample properties of the sample. Specifically, a bootstrap of the common shocks, $\tilde{\boldsymbol{u}}_{\boldsymbol{t}}$, is used to generate new static factors $\tilde{\boldsymbol{f}}_{\boldsymbol{t}}=\hat{\boldsymbol{D}}(L)^{-1} \hat{\boldsymbol{R}} \tilde{\boldsymbol{u}}_{\boldsymbol{t}}$. Reestimating the VAR model in equation 3, the spectral decomposition of the accompanying 
variance-covariance matrix of equation 4 along with the identifying restrictions discussed below yields new bootstrapped impulse responses. The median and the relevant percentiles of the distribution of these new impulse responses lead to point estimates and confidence bands, respectively.

\subsection{A multi-country structural dynamic factor model for the US and the EA}

With the implementation of the euro in 1999 and the transfer of the individual central banks' monetary policy mandate to the ECB, the EA member countries have undergone a major structural transformation. In order to account for this change in the institutional framework, I follow Barigozzi et al. (2014) and Hanisch (2017) in modifying the estimation procedure presented above as follows. First, both the static factors and the common shocks are estimated over the whole sample. Second, a breakpoint in 1999.I is introduced into the model and the factor loadings are jointly estimated for both subsamples. Third, the US monetary policy shock is identified and the structural impulse response functions are estimated for both periods. This procedure yields two main advantages:

(1) Estimating the static factors and common shocks over the whole sample yields a common source of variation. The EA member countries are thus confronted with the exact same shock in both subsamples which makes the results directly comparable. Following this approach I do not have to resort to estimating separate models. The procedure allows me to avoid using shocks from different data sets which could impede a clean comparison between individual countries and time periods. ${ }^{1}$

(2) Estimating the factor loadings separately in both subsamples accounts for the change

\footnotetext{
${ }^{1}$ Section 3.2 and 5.3 deal with issues regarding the inclusion of post-2008 data in the benchmark model.
} 
in the institutional EA framework. Confronted with the same US shock, individual EA member countries are thus allowed to behave differently when they are part of the EA as opposed to the period before the single currency was introduced.

It may be argued that structural macroeconomic changes have already been triggered as early as 1979 with the implementation of the European Monetary System, under which the member countries intended to stabilize exchange rate fluctuations among each others' currencies. Also, following the Maastricht Treaty of 1992, EU member countries embarked on an irreversible course towards the eventual introduction of the single currency at the end of the 1990s. However, these changes rather resemble a process of gradual transition, implemented with varying focus and speed in the different countries. In this context, Stock and Watson (2002) show that the space spanned by the static factors is consistently estimated even in the presence of limited time variation in the factor loadings. A CUSUM square test on the stability of the static factors finds no significant structural changes. ${ }^{2}$ Still, Breitung and Eickmeier (2011) demonstrate that in the presence of major structural breaks, factor loadings are estimated inconsistently. In order to formally test this assumption, I apply the Breitung and Eickmeier (2011) test for a breakpoint in the factor loadings. ${ }^{3}$ The results in Table 1 indicate the presence of a structural break on January 1st 1999 in the EA countries for all major economic indicators.

\section{Insert Table 1 here}

Similar results are reported by Barigozzi et al. (2014). I follow this line of argument in setting the breakpoint for the factor loadings to 1999.I. The period before the introduction

\footnotetext{
${ }^{2}$ Results are available from the author upon request.

${ }^{3}$ I would like to thank Sandra Eickmeier, Matteo Barigozzi and Matteo Luciani for their kind help regarding the stability tests.
} 
of the euro is referred to as 'pre-euro period'. Consequently, the period beginning in 1999.I is termed as 'euro period'.

\section{Data and model setup}

\subsection{Data}

The major part of the data set comprises macroeconomic variables for the US and the EA countries Germany, France, the Netherlands, Italy and Spain. Each country is represented by a set of about 30 variables that is balanced between real and financial indicators. The economic categories are the following: national accounts, prices, income and consumption, the labor market, monetary aggregates, interest rates, financial markets (i.e. bond, stock and credit markets) and business conditions and the foreign exchange market. For the US, the Gilchrist and Zakrajšek (2012) spread, the mortgage spread, defined as the 30year mortgage rate minus the 10-year Treasury rate, and the excess bond premium are included as in Gertler and Karadi (2015). These indicators are crucial to capture US credit shocks, especially during the global financial crisis. The data set further contains 12 EA aggregates from the same categories as well as the world aggregate of GDP, consumer prices and the world commodity price index of crude oil. Finally, in order to account at least partially for the remaining EA countries, the data set is augmented with GDP, CPI and (where available) short- and long-term interest rates of Ireland, Finland, Portugal and Belgium. The data set consists of 244 quarterly macroeconomic key variables covering the US and the major part of the EA, spanning the period 1983.I - 2015.I.

The starting point of the data set in 1983 is mainly motivated by the monetary policy strategy pursued by the Federal Reserve. As Bernanke and Mihov (1998) note, US mo- 
netary policy before 1983 targeted non-borrowed reserves. The switch towards targeting short-term interest rates occurred in late 1982. This coincides with the Federal Reserve's stronger emphasis on the goal of achieving and maintaining price stability after the experience of intense macroeconomic volatility in the late 1970s, as Clarida et al. (2000) suggest. In order to rule out any substantial structural changes in the conduct of US monetary policy on the part of the Federal Reserve, the data set starts in 1983.I.

In order to account for the intermediate period starting in 2008 that led to an economic environment of very low interest rates both in the US and the EA, I incorporate the Wu and Xia (2016) shadow Federal Funds and ECB rates into the model. Using 1month forward rates for maturities between 3 month and 10 years, a term-structure model extracts information from a set of variables that yield meaningful variation even when short-term rates are essentially stuck at zero. The resulting shadow rate is then treated as an observable that captures both conventional and unconventional monetary policy measures. By replacing the period of zero interest rates with the constructed shadow rates, Wu and Xia (2016) introduce a measure of monetary policy that consistently reflects the state of the economy of both the US and the EA throughout the sample period employed here. $^{4}$ This strategy is also applied by von Borstel et al. (2016) and Conti (2017), among others.

Following Forni and Gambetti (2010) and Luciani (2015), transformations are kept to a minimum. Time series not available in seasonally adjusted format are adjusted using the X-13-ARIMA procedure (except for interest rates and exchange rates). Where appropriate, the first differences of the logs of variables are used to achieve stationarity, except for interest rates and nominal exchange rates. A complete list of variables and ${ }^{4}$ See Section 5.3 for a discussion of conceptual issues regarding the use of shadow rates. 
transformations is provided in Appendix A. In order to prevent scale effects, all variables are standardized to have zero mean and unit variance prior to the estimation. The nonstructural impulse responses in equation 6 are de-standardized using their pre-estimation standard deviations such that the scales of the results can be interpreted the way the variables enter the model, i.e. mainly in growth rates except for interests rates and nominal exchange rates which enter in levels.

\subsection{Identification}

Following Uhlig (2005) and Fry and Pagan (2011), I employ sign restrictions and combine them with magnitude restrictions that identify a traditional contractionary US monetary policy shock along the lines of Gertler and Karadi (2015), Luciani (2015) and Dedola et al. (2017). As the impact of the shock on the US economy itself is only of minor interest here I apply a range of restrictions the aforementioned literature attributes to a US policy shock in order to ensure proper identification. Specifically, I impose the following restrictions.

The augmented Federal Funds Rate (FFR) is set to increase. This is an obvious choice as the FFR is the main US interest rate through which monetary policy is conducted. I assign an additional sign restriction to the two-year US government bond rate (2-Year GB) which, as Gertler and Karadi (2015) argue, also captures shocks to forward guidance. The concept of forward guidance basically entails the managing of agents expectations regarding the path of future interests rates. Swanson and Williams (2014) make the case that the Federal Reserve's forward guidance strategy aims to manage these expectations within a roughly two-year horizon. As this tool is increasingly relied upon, especially

since the global financial crisis, Gertler and Karadi (2015) argue that such a short-term 
government bond is a proper indicator that accounts for surprises in the forward guidance about the path of future rates. An unexpected US monetary tightening is thus only identified as such if in addition to the policy rate the two-year US government bond rate increases. The additional sign restriction should lead to a more specific gauge of the stance of US monetary policy and make it more separable from other shocks. As Swanson and Williams (2014) argue, two-year bonds retained flexibility also in the aftermath of the global financial crisis. The restriction should thus make the results more robust to the estimation of the shock over the whole sample which includes the post-2008 period.

The remaining sign restrictions on US variables are well established. Output and inflation decrease. To ensure that the increase in interest rates is driven by a monetary policy shock rather than a money demand shock, monetary aggregates are also restricted to decrease. Specifically, output is measured by GDP and inflation by CPI and the GDP deflator. M1 is used as a monetary aggregate.

Finally, I impose a magnitude restriction which requires the differential between individual EA interest rates and the augmented FFR (Diff $\left.I_{\text {IntR }}\right)$ to be negative on impact. This constraint implies that the initial responses of EA monetary authorities are not larger than the shock itself (but free to evolve thereafter). As Dedola et al. (2017) argue, the environment of simultaneously very low interest rates in many advanced economies and the high degree of policy coordination since 2008 impede a sharp distinction between individual policy shocks. In order to accurately disentangle the individual policy shocks from each other, the interest rate differential ensures a focus only on those US policy shocks that are at most weakly correlated with EA policy shocks. Hence, the restriction also acts as an additional safeguard against putting too much weight on contractionary 
shocks during the post-crisis period.

Insert Table 2 here

The shock is thus identified locally, i.e. sign restrictions are imposed on US variables only. I consciously stay agnostic with respect to the signs of all non-US variables since the spillover effects on the EA member countries are of main interest. Moreover, I also stay agnostic with respect to US variables related to the foreign exchange market, i.e. exchange rates, US Terms of Trade and US imports and exports. As these variables already contain information regarding the relation with non-US economies, restricting them would anticipate some of the main results. ${ }^{5}$ The benchmark sign restrictions are summarized in Table 2.

\subsection{Number of factors}

To determine the number of static factors $r$, I employ the $I C_{1}$ and $P C_{1}$ criterion suggested by Bai and $\mathrm{Ng}$ (2002). These criteria search for the number of static factors that minimizes the contribution of the idiosyncratic component to the variation in $x$. The integer minimizing the criterion functions determines $r$. Table 3 presents the percentage share explained by the $i$-th static eigenvalues of the variance covariance matrix of $x$ (in decreasing order) and the $I C_{1}$ and $P C_{1}$ criterion test results.

\section{Insert Table 3 here}

The test statistics suggests the presence of $\hat{r} \in\{8 ; 12\}$ static factors. In order to

${ }^{5}$ Section 5 considers various alternative identification schemes including direct restrictions on the US exchange rate. 
determine the number of common shocks, I employ two criteria. The first is developed by Hallin and Liska (2007) which does not depend on the number of static factors and suggests $\hat{q}=4$. Second, Bai and $\mathrm{Ng}$ (2007) provide a criterion based on the number of static factors. The test, based on the covariance matrix of the residuals from estimating a VAR on the static factors, suggests $\hat{q}=3$ for $\hat{r}=8$ and $\hat{q}=5$ for $\hat{r}=12$. Bai and Ng (2007) and D'Agostino and Giannone (2012) state that, given the number of common factors, $r$ and $q$ will explain the same amount of variation in the data. Table 4 reports the cumulative explained variance of the first $\hat{r}$ common factors and the first $\hat{q}$ common shocks.

\section{Insert Table 4 here}

For $\hat{r}=8$, it is $\hat{q}=4$ common shocks that explain the same amount of variation, supporting the Hallin and Liska (2007) test results. This is a reassuring outcome as similar combinations of static factors and common shocks are found to describe both the EA (Eickmeier, 2009; Barigozzi et al. 2014) and the US economy (Forni and Gambetti, 2010; Luciani, 2015). Furthermore, the common component accounts for a substantial share of explained variance of macroeconomic key variables in the individual countries, summarized in Table 5.

\section{Insert Table 5 here}

Hence, this combination is accepted as the benchmark setup. ${ }^{6}$

\footnotetext{
${ }^{6}$ Variations on the combination of static factors and common shocks as suggested by the information criteria leave the results mainly unaltered. Results are available from the author upon request.
} 


\section{Results}

Results are presented by means of impulse responses to a contractionary US monetary policy shock. In order to make the results in both subsamples comparable, they are normalized to represent responses to a policy shock that increases the Federal Funds Rate by 50 basis points.

\subsection{Responses of US variables}

In order to motivate the nature of the shock, this section briefly presents the responses of the variables used for identification and additional US key indicators. As the breakpoint in 1999.I has no clear economic interpretation for the US economy, Figure 1 presents responses to the monetary policy shock estimated over the whole sample.

\section{Insert Figure 1 here}

After the initial increase of the imposed 50 basis points, the augmented Federal Funds Rate reverts back towards its baseline level with long-term government bond yields following a similar development. Real output and prices fall and the real exchange rate appreciates. Credit spreads increase, indicating the tightening of financial conditions. Stock prices increase slightly on impact but revert into negative territory quickly. The US monetary policy shock is thus largely characterized by responses similar to those reported previously in the literature (Uhlig, 2005; Neri and Nobili, 2010; Gertler and Karadi, 2015; Luciani, 2015). 


\subsection{Responses of individual EA member countries}

In this section, discussion turns to the main question of the paper, i.e. the spillover effects of contractionary US monetary policy on selected EA member countries before and after the implementation of the euro.

From a theoretical point of view, several channels affect the outcome of such an impulse for the EA. Through the trade channel, the increase in US interest rates is usually followed by an appreciation of the US dollar and every currency that is in any way pegged or attached to it. ${ }^{7}$ The equivalent deprecation of free floating currencies leads to a competitive advantage in these countries and increases demand for comparably cheaper export goods. This is the expenditure-switching effect which triggers an economic expansion abroad. Contemporaneously, the increase in US interest rates reduces US income and demand. Due to this opposing income effect economic activity decreases elsewhere as demand for imported goods into the US diminishes.

Given the pivotal role the US hold in global financial markets, effects from monetary policy may also disperse internationally via the financial channel. If central banks follow the lead of the Federal Reserve they induce a domestic income effect. This effect may also trickle through to longer-termed bond yields. Bekaert et al. (2013) and Rey (2015) observe a strong comovement in global risky asset prices and capital flows which they find to be strongly affected by Federal Reserve decisions on its main interest rate. If the leverage of global banks and their willingness to engage in risky transactions is driven by US monetary policy rather than by domestic economic conditions, credit may become too scarce or too loose, potentially threatening financial stability. This implies another ${ }^{7}$ See Ilzetzki et al. (2017) for a survey on the US dollar as the world's dominant anchor currency. 
channel through which decisions by the Federal Reserve may transmit internationally.

The implementation of the euro further complicates matters. If countries become more integrated - which is a direct objective within the currency union - this should lead to larger spillovers. Via the trade channel, the income effect described above may be stronger between countries that trade more with each other. Financially integrated countries are more prone to sudden stops and contagion (Georgiadis, 2016). However, if the EA member countries become more integrated with each other it is a-priori not evident to what extent this process affects the impact of disturbances that stem from outside the EA.

The overall theoretical cross-country effect is thus not uniquely determined as several of the transmission channels work in opposing directions and some may be more important for certain countries than others. The EA membership potentially further affects the transmission of the shock. Ultimately, it is then an empirical task to quantify the total effect and the relative strength of the individual transmission channels.

To this end, in the following figures the solid grey lines represent the responses in the 1983.I-1998.IV subsample and the solid black lines represent the responses in the 1999.I2015.I subsample. The shaded area and the dash-dotted lines mark the corresponding $84 \%$ confidence bands, respectively. Figure 2 reports the responses of output and inflation in the individual countries.

\section{Insert Figure 2 here}

Heterogeneity among the responses is large, especially in the pre-euro period. German GDP increases substantially while the response of Spanish output is muted and temporarily negative. Output responses of the remaining countries lie in between. Furthermore, 
in Germany the positive output effect takes the longest to fade out while most other countries experience a rather short-lived economic expansion. Conversely, German prices react subdued while inflation in the Netherlands, Italy and Spain picks up more strongly. This is a noteworthy finding because it helps to understand the large heterogeneity among the signs of the effects reported previously in the literature. Most studies mentioned above rely on aggregates of different groups of countries. However, if the countries themselves react differently, the responses of aggregates will not provide conclusive evidence. The results reported here illustrate that even among the group of the largest EA member countries heterogeneity is substantial. As opposed to VARs or GVARs, all countries are described in great detail and modelled jointly in the framework of a dynamic factor model. Accounting for simultaneous interactions with their most important trading partners and higher-order spillovers should lead to plausible estimates (Georgiadis, 2017). Furthermore, all countries are confronted with the exact same common shock. These features make the results directly comparable across countries and help to uncover important differences previously undetected. Most notably, the results suggest that contractionary US monetary policy does not necessarily lead to a symmetric decrease of economic activity elsewhere, but may actually induce a short-lived economic expansion in some countries.

Moreover, the approach chosen here not only allows for an investigation across countries but also across time. Interestingly, the broad range of results is found to respond more homogeneously after the implementation of the euro in 1999. Similar to the pre-euro period, GDP increases following the shock. However, initial responses are lower in most countries, most notably in Germany. The reaction of Spanish output is - though small - unambiguously positive. Furthermore, the positive effects are more prolonged, taking 
longer to return to the baseline level. Prices follow a similar development. Responses are mainly smaller during the euro-period, although uncertainty surrounding the estimates is relatively large. The combined responses of output and inflation suggest the shock to have transitory supply-side type effects, most notably in Germany and to a lesser extent in France and Spain, but only during the euro period in the latter two countries. Estimation uncertainty is comparatively large which impedes a clear-cut conclusion. Still, the possibility of temporarily subdued inflation rates combined with an increase in output is a feature of international spillover effects previously undetected.

In order to illustrate some of the underlying drivers of the observed effects on output and prices, Figure 3 presents selected results from individual national accounts.

\section{Insert Figure 3 here}

Investment increases are strong in the two industrialized economies of Germany and the Netherlands and similar findings apply to private consumption. In accordance with the subdued output responses in Italy and Spain, both indicators hardly pick up in these countries. The development towards more harmonized responses after 1999 is also present here, supporting the notion of increased homogeneity in the latter part of the sample. Thus, while the benefits and costs of the spillover effects are distributed rather unevenly in the pre-euro period, responses of real activity and inflation broadly converge over time, indicating increased homogeneity among the EA members in the euro period.

Three main results emerge. First, spillover effects stemming from a contractionary US monetary policy shock cause a mainly short-lived expansion of EA national accounts, such as real output and investment. Second, the results reveal an overall reduction in 
the effects of the shock after 1999. Third, responses of variables from both the national account and price categories exhibit more similar responses after the implementation of the euro, suggesting increased homogeneity across EA member countries. These findings complement those presented by Boivin et al. (2008) and Barigozzi et al. (2014), who report similar dynamics for a domestic EA monetary policy shock after 1999.

\subsection{Detailed transmission mechanism}

In order to better understand the dispersion of US monetary policy and its effects on the EA member countries this section exploits the large variety of economic indicators present in the data set to explore the relevant transmission channels. Beginning with the trade sector, Figure 4 presents the responses of both nominal and real effective exchange rates and net exports. Nominal exchange rates prior to the introduction of the euro in 1999 are the respective countries' former currency expressed in euro terms.

\section{Insert Figure 4 here}

Following the contractionary US monetary policy shock, both nominal and real effective exchange rates depreciate in most countries. During the pre-euro period, the responses especially of the real effective exchange rates show broad heterogeneity. Following the shock, France, Germany and the Netherlands observe the maximum depreciation on impact and a gradual transition back to their baseline level within seven to nine month. However, in Italy and Spain real effective exchange rates response are more volatile, even showing signs of a temporary appreciation. This finding complements the results reported

in Boivin et al. (2008) who report comparably strong and volatile responses of Italian and 
Spanish exchange rates following an EA monetary policy shock. The range of responses of net exports is mostly in line with those observed for output in the pre-euro period, i.e. net increases in exports in Germany are rather strong while on the lower end subdued and surrounded by high estimation uncertainty in Spain. In general, this speaks in favor of the expenditure-switching effect.

After the implementation of the euro both nominal and real effective exchange rates are found to be less responsive to the foreign shock. Regarding the nominal exchange rate, the observed homogeneity among the responses follows by construction as all countries commonly use the euro as their single currency in this period. However, real effective exchange rates exhibit similar dynamics, i.e. a depreciation, although smaller in size. ${ }^{8}$ This finding confirms the earlier result of subdued inflation responses during the euro period. The reduced responsiveness of exchange rates after 1999 is reflected in overall positive, but significantly lower net exports. This corroborates the general result of an increasingly homogeneous - but lower scale - response to the foreign monetary policy shock among EA member countries after the implementation of the euro. Noteworthy is the small, but now unambiguously positive, response of the Spanish trade sector (see section 4.4 for a discussion). Thus, trade is found to serve as an important transmission channel through which the reported movements in individual national accounts materialize.

Discussion now turns to the role of interest rates and financial markets. In order to analyze whether and to what extent the foreign policy shock affects the conduct of domestic monetary policy, the top and middle row of Figure 5 present selected responses of the interest rates category.

\footnotetext{
${ }^{8}$ Real effective exchange rates may differ also after the implementation of the euro due to the consideration of the individual countries' price developments.
} 
Insert Figure 5 here

The overall response of interest rates is positive. As imposed by the sign restrictions, the initial responses are smaller in size than that of the shock. Thus, the central banks partially offset the economic expansion reported above. Endogenous monetary policy responses are a frequently reported feature of cross-country spillover effects (Kim and Roubini, 2000; Neri and Nobili, 2010).

In the pre-euro period, policy interest rates reveal a certain level of inertia, i.e. the maximum increase appears only shortly after the shock occurs. The delayed peak is in accordance with the observed humped-shaped pattern of output and price responses, i.e. the full effect of the foreign shock develops with a time lag. Also, Bjørnland and Halvorsen (2014) note that gradual movements in interest rates are used as a tool to affect private-sector expectations regarding the future path of monetary policy actions. A notable exception is Spain, where the policy interest rate decreases on impact and turns insignificant quickly. However, given the subdued response of Spanish pre-euro output, pressure on the central bank to mitigate the effects of the shock is likely to be contained.

The similarity of the policy rate responses in the euro period is by construction since all EA member countries commonly have adopted the interest rate of the ECB as their main policy rate in that period. In accordance with the overall muted responses after the implementation of the euro, the policy rate initially increases, but on a lower scale. Thus, both the timing and the size of the responses leave room for the expenditure-switching effect to unfold before the negative income effect, induced by the increase in domestic interest rates, sets in.

Responses of long-term government bond yields follow a similar pattern. While pre- 
euro responses of Italian and Spanish bond yields are among the highest, these differences broadly level out after 1999. This is in line with Boivin et al. (2008) who argue that a decrease in the risk premium accompanying the membership in the EA markedly contributes to lower long-term bond yields. In this context, Bekaert et al. (2009) argue that increasing integration of Europe into global markets may be an additional driver of the observed comovements in financial markets in the latter part of the sample. This finding is further corroborated by the responses of individual stock markets, depicted in the bottom row of Figure 5. Comparable to long-term bond yields, movements of stock markets can be interpreted as a proxy for investors' sentiment regarding the state of the economy. Share prices in Italy and Spain fall during the pre-euro period, possibly driven by the perception of uncertainty induced by volatile price and exchange rate responses. During the euro period, these differences broadly level out as initial reactions become positive in all countries. The initial increase may partly be also induced by the short-term expansion of the US stock market. Spillover effects of that kind are more likely the higher the degree of financial markets integration. However, stock prices quickly turn negative in most countries before the effects return to the baseline. This is in line with the rather short-lived nature of the EA economic expansion and the leading role of the US.

As global financial markets become deeper integrated, the role of credit markets has attracted increased attention. The build-up of large short-term, often US-dollar denominated credit positions and the sometimes abrupt reversal of cross-border credit flows threatens financial stability in the affected countries (Rey, 2015; Bruno and Shin, 2015). For the EA, Gambetti and Musso (2017) identify domestic loan supply to have significant effects on economic activity, potentially causing higher-order spillover effects on its own. 
In order to analyze the susceptibility of individual EA member countries' banking sectors to foreign shocks and the role of credit in this context, Figure 6 presents the responses of credit markets.

Insert Figure 6 here

Cross-border credit inflows commonly decrease which Miranda-Agrippino and Rey (2015) associate with a deterioration in global credit conditions due to the tightening in US monetary policy. The responses of domestic credit in contrast are largely positive, although not exclusively so. While domestic credit increases in Germany in the pre-euro period, the response in France is negative and insignificant in the Netherlands and Italy. During the euro period, responses become positive in all countries but - comparable to stock markets - in varying strength. US monetary policy thus clearly constitutes a disruptive force for the EA banking sector. However, responses reveal its impact in the individual countries to be highly idiosyncratic, especially in the early part of the sample, with domestic factors playing a large role.

Responses of house prices are even more dispersed, as depicted in Figure 7.

Insert Figure 7 here

In general, US monetary policy is found to have an impact on individual EA housing markets, a transmission channel also reported by Musso et al. (2011) and Dedola et al. (2017). On impact, responses are mainly positive in the pre-euro period but turn insignificant quickly. While this pattern is maintained in Germany and the Netherlands after 1999, initial responses turn negative in France, Italy and especially in Spain. The 
latter development can in parts certainly be attributed to the severe turmoil the Spanish housing market slipped into after 2008. House prices, comparable to credit markets, are thus sensitive to foreign shocks. However, strength and direction of individual responses appear to be strongly dependent on domestic economic conditions.

\subsection{Discussion}

Among the main features of the results presented above is the rather homogeneous responsiveness of many EA member countries' individual variables as compared to their pre-euro dynamics. The observation of a trend towards a broad alignment across a range of real and financial variables suggests that the adoption of the euro has enhanced the economic integration within the EA, as also noted by Inklaar et al. (2008). Intra-EA trade represents the highest share of exports and imports among the individual EA member countries such that the impact of a foreign shock via the trade channel becomes less disruptive. In fact, the observed small increase of Spanish net exports after 1999 may very well arise due to increasing intra-EA demand, e.g. for intermediate goods. In this context, Georgiadis (2015) notes that promoting financial and capital market integration and eliminating product and labor market frictions reduces the sensitivity to foreign monetary policy shocks. Remaining differences in the responses during the euro period therefore point towards different levels of implementation of these measures and different convergence rates among the EA member countries. Thus, the idiosyncratic, i.e. the country-specific, component retains substantial influence which is to be expected from a union of individual countries in which main policy responsibilities remain at the national level. This directly implies that foreign shocks, though on a smaller scale, continue to 
potentially affect economic stability of the EA.

Previous evidence regarding the direction of the response of EA output to a contractionary US monetary policy shock is inconclusive, as Kim and Roubini (2000) and Neri and Nobili (2010) report increased economic activity while Bluedorn and Bowdler (2011), Georgiadis (2016) and Dedola et al. (2017) document recessionary effects. The findings in this paper - mainly, but not solely, positive responses that vary over time - lie in between. Taking into account the predominance of the US dollar as the main international medium of payment, the results reported here seem plausible given that many countries use the US dollar as their main currency. A depreciation of the euro is therefore likely to improve trade balances of EA member countries also against countries other than the US. Furthermore, not only bilateral exchange rates against the US dollar but also effective exchange rates against a basket of currencies are found to depreciate. The expenditure-switching effect is therefore likely to occur not only in the US but also in a wider range of countries whose exchange rates are tied to the US dollar. This also helps to rationalize why the spillover effects in some countries - most notably Germany - are larger in absolute terms than the domestic impact in the US, a finding also reported by Maćkowiak( 2007) and Georgiadis (2016). In this context, Georgiadis (2017) demonstrates that estimates of international spillover effects tend to be more accurate, and along with it larger, if the econometric model comprises information about higher-order spillovers and spillbacks from third countries. This is accounted for here as the EA countries are heavily and increasingly engaged with each other through economic and political ties which should lead to higher - and more accurate - spillover estimates.

The predominance of the US dollar also plays a crucial role for international credit 
markets. In this context, Bekaert et al. (2013) and Rey (2015) attribute strong influence to the stance of US monetary policy through what they call the global financial cycle. This feature is also present in the results reported here, as cross-border credit commonly decreases on a relatively large scale due to increased costs of foreign currency borrowing following the increase of US interest rates and the associated appreciation of the US dollar. In contrast, domestic credit markets are largely documented to increase. This supports the hypothesis of Miranda-Agrippino and Rey (2015) who argue that in the presence of a global financial cycle - which they find to be strongly influenced by decisions of the Federal Reserve - even fully flexible exchange rates are not able to completely absorb the effects of a shift in global credit conditions. The exchange rate depreciation found here may thus not be sufficiently accommodative to counterbalance the decrease of international credit. This essentially induces another switching effect (which accompanies the expenditure-switching effect related to the trade channel) towards domestic credit markets where interest rates increase only with a delay and less than one-to-one. After 1999, the credit channel seems to work more evenly across all EA member countries considered here. This finding lends support to the hypothesis that the structural measures designed to intensify integration among the member countries in the EA do show some effect in the sense that EA credit markets serve at least partially as a substitute for global credit markets. However, while the impact of foreign shocks is found to be contained in the latter part of the sample the EA continuously finds itself being exposed to such disruptions which potentially threaten financial stability. A similar reasoning applies to EA stock markets. After an initial increase that accompanies the short-lived economic expansion responses turn negative quickly, thus following the lead of global financial conditions influenced by US monetary 
policy. This is largely in line with Bekaert et al. (2013) and Rey (2015) who attribute the high degree of comovement in stock markets to the presence of the global financial cycle.

The relatively large spectrum of responses reinforces the argument that working with aggregates hardly allows for inference regarding the reaction of individual countries. The reported zero response of an EA wide aggregate of real credit by Dedola et al. (2017) to a contractionary US monetary policy shock may very well arise due to the underlying heterogeneity among the individual countries uncovered here. A similar reasoning applies to the broad range of results regarding the direction of the responses of output reported previously in the literature. Furthermore, besides the traditional transmission channels of trade and interest rates, I find markets for stocks and housing to play an active role in the dispersion of the US shock. This highlights the importance not only to investigate spillover effects in a multi-country setting, but also to characterize each country in the greatest possible detail in order to account for the various channels through which the shock materializes. The analysis conducted here - covering a wide range of economic indicators jointly on the country level, confronting them with the exact same shock - is thus crucial for a comprehensive understanding of the multilateral transmission channels of the US shock.

\section{$5 \quad$ Robustness analyses}

\subsection{Testing cross-country asymmetries}

Statistical significance regarding the time profile of the responses within each country is directly observable from the figures presented above. However, this is not the case for cross-country comparisons, i.e. the observation of an overall reduction in the size of 
the responses does not necessarily imply that the countries become more similar. Thus, it is not immediately inferable whether the individual countries converge towards each other in a statistically significant manner. In order to test this issue, I follow Peersman (2004) and Barigozzi et al. (2014) by taking differences between the estimated individual responses and - as a benchmark - the EA-wide response of the same variable. Confidence bands containing the zero are interpreted as differences not statistically different from the benchmark. Since the benchmark response serves as an anchor and is common to all countries, responses closer to zero are interpreted as an increase in homogeneity as they imply a smaller difference to the EA-wide response. Figure 8 presents results for selected key variables.

Insert Figure 8 here

During the pre-euro period, heterogeneity among the responses proves to be substantial. Differences from EA-wide responses are large especially for output and long-term government bond yields. The increase in German output exceeds the EA-wide surplus most while German and also French long-term bond yields increase comparably less, indicating confidence in the two biggest economies of the EA to be relatively strong. On the other end, Italian and Spanish output responses lag behind with especially Italian bond yields increasing strongly. A similar pattern holds true for the development of the CPI. Hence, this exercise confirms that the pre-euro period is characterized by substantial cross-country asymmetries.

After the implementation of the euro these differences are found to converge in a statistically significant manner. All responses approach the EA average such that convergence 
among the individual EA member countries is validated. German output continues to exceed the EA average but by a smaller margin while output responses of the remaining countries are able to catch up. Similar dynamics are revealed for the long-term bond yield and CPI responses, the latter possibly reflecting the influence of the ECBs' inflation targeting strategy. Thus, while certain cross-country asymmetries remain, the rather homogeneous responses during the euro period are indeed found to be the result of a statistically significant convergence process.

\subsection{Variations on the identification scheme}

I discuss the sensitivity of the benchmark results to five alternative identification schemes of the US monetary policy shock. First, to ensure that the shock originates in the US in the sense that it is not induced by foreign interest rate movements, as an additional sign restriction the US real effective exchange rate is required to appreciate on impact (Alternative 'I'). Second, in order to evaluate to what extent the sign restriction on US output drives the benchmark results, in a further variation on the identification scheme, US GDP is left unrestricted (Alternative 'II'). In a similar manner, I stay agnostic with respect to the response of US inflation and require the world price of oil to decrease instead (Alternative 'III'). I also consider a more conservative identification scheme proposed by Georgiadis (2016), where the US interest rate is required not to decrease on impact and the US CPI does not increase after 4 quarters, in order to account for the stickiness of prices. In order to preserve consistency with the forward guidance argument and to keep correlation between individual policy shocks in check during the post-2008 period, I keep the restriction on the US 2-year government bond rate and the interest rate differential. 
The responses at shorter horizons of US inflation and all other variables remain unrestricted (Alternative 'IV'). Finally, I consider the possibility of lagged responses of US output and inflation to the monetary policy shock. Specifically, on impact I restrict US output and inflation not to respond at all. This is achieved by rotating the candidate matrix $\hat{\boldsymbol{c}}_{\boldsymbol{i}}(L)$ using an appropriate Givens rotation along the lines of Eickmeier and Hofmann (2013) and Gambacorta et al. (2014) which sets the required entries to zero. As in the benchmark model, US interest rates do not decrease and monetary aggregates do not increase. In contrast to the benchmark model, all restrictions are imposed on impact only (Alternative ' $\mathrm{V}$ '). The sign restrictions of all alternative specifications are summarized in Table 6 .

\section{Insert Table 6 here.}

Results are presented as differences to the EA aggregate response from the benchmark model. As in Section 5.1, confidence bands containing the zero are interpreted as models not statistically different from each other. In Appendix B, Figure B.1 reveals that the nature of the spillover effects on EA aggregate output and inflation does not hinge on the identification of the US monetary policy shock. If any, deviations are larger for Alternative IV, but only during the pre-euro period and insignificant for the overwhelming part of the forecast horizons. Thus, the responses arising from alternative identification schemes are closely related to those obtained from the benchmark model, especially for the later part of the sample. 


\section{$5.3 \quad$ Sample length}

As outlined in Section 3, I employ the Wu and Xia (2016) shadow rates in order to account for possible changes in the conduct of monetary policy on the part of both the Federal Reserve and the ECB since late 2008. However, a switch in the monetary regime may have broader effects on the economy than the shadow rate is able to capture. A further issue relates to the use of the shadow rate itself as a measure of monetary policy. The $\mathrm{Wu}$ and Xia (2016) shadow rate is based on the term structure of interest rates. Even though central banks have influenced the term structure, especially after 2008, factors like financial market participants' expectations and investors' flight into save assets also have an impact on its composition. Shadow rates further are sensitive to the exact specification of the model which suggests its use as an indicator of monetary policy at the zero lower bound to be problematic (Bauer and Rudebusch, 2016). It may thus be instructive to investigate the influence of the post-2008 data on the benchmark results by dropping the respective period.

A similar reasoning applies to the European sovereign debt crisis and the environment of low inflation that emerged since 2012. Conti et al. (2015) make the case that the ECB had an active role in further decreasing EA inflation until early 2014. As interest rates where restricted by the lower bound, falling inflation expectations have increased the real interest rate. This effect resulted in an unwanted tightening of monetary conditions and aggravated already weak demand which led to the launch of the asset purchase program in 2014. Thus, I re-estimate the model presented above with the sample cut in 2008.III and 2012.I, respectively. Selected results for the euro period are presented in Appendix B in Figure B.2. For comparison, the benchmark responses from the 1999.I-2015.I period 
are also included, marked by the solid grey lines and the shaded areas. The estimated median responses to the US monetary policy shock do not reveal substantial asymmetries. Responses for the sample cut in 2008.III tend to be slightly smaller on average. Inflation responses for the sample cut in 2012.I are estimated to be larger by a small margin which attributes a certain impact to the low inflation environment on the benchmark results. The estimated Italian output response is also slightly larger, reflecting the negative impact of the post-2012 sovereign debt crisis which is especially persistent in Italy.

Still, overall differences are small and mostly contained within the credible sets of the benchmark model for the overwhelming part of the forecast horizons. This does not necessarily imply that the nature of the spillover effects is not affected by the events discussed in this section. However, the inclusion of shadow rates as well as the chosen identification scheme appear to sufficiently account for the post-crises environment such that the main conclusions can be upheld when the respective periods are included. This mirrors the findings of Miranda-Agrippino and Rey (2015) and Georgiadis (2016) who find the macroeconomic dynamics of the spillover effects of US monetary policy not to be fundamentally different after 2008.

\section{Conclusion}

The main objective of this paper is to assess the macroeconomic cross-country spillover effects of a contractionary US monetary policy shock on the euro area (EA). To this end, I estimate a multi-country structural dynamic factor model on a data set spanning 244 macroeconomic key variables, describing the economies of the US, Germany, France, the

Netherlands, Spain and Italy. The large amount of information present in the model allows 
for a broad analysis of the effects on economic activity and price inflation and sheds light on the various transmission channels through which these spillover effects materialize.

The results, found to be robust to various alterations in the model setup and sample length, can be summarized as follows. In general, spillover effects on EA member countries are asymmetric. Real activity and inflation mainly increase, but not exclusively so, and the effects are rather short-lived. Regarding the transmission channels, nominal and real exchange rates depreciate and net exports increase, suggesting trade to be an important driver of the EA economic expansion. EA interest rates increase with a delay, allowing the expenditure-switching effect to unfold before the offsetting income effects sets in. The financial sector, represented by bond, stock and credit markets, is found to serve as an active transmission channel, albeit with varying strength and direction. US monetary policy is thus found to have a substantial impact on individual EA economic and financial stability.

While the spillover effects in the pre-euro period are found to be diverse and heterogenous, an important outcome of the analysis is that these differences broadly level out after the implementation of the euro, resulting in more homogeneous and overall smaller responses. These findings suggest that the euro as the single EA currency is less responsive to the US monetary policy shock as compared to the individual currencies that existed before 1999. The increased homogeneity is found to be the result of a statistically significant convergence process, both across countries and across time. This process entails lower output responses for some countries, most notably Germany, but higher output responses for others, e.g. Spain. As part of the EA, indicators that illustrate markets' perception with respect to expected economic conditions broadly align, especially in Spain 
and Italy. The results suggest that joining the EA is able to strengthen investors' trust which is accompanied by decreased risk premia. These developments render the impact of a foreign shock less severe. The results presented here extend and complement the findings of Boivin et al. (2008) and Barigozzi et al. (2014), who document increased homogeneity among EA member countries in response to an EA, i.e. a domestic, monetary policy shock.

However, cross-country asymmetries between the individual responses remain, highlighting that differences regarding the progress of implementing these measures add to the current persistence of individual economies' diverse structural characteristics. Asymmetries in the effects of a foreign shock complicate and aggravate an adequate response on part of the European Central Bank (ECB). Immediate measures to counteract a foreign shock, such as movements in the policy interest rate, affect all EA member countries equally. If the responses of individual countries are asymmetric, an appropriate policy response that minimizes the impact while mitigating the associated risks is difficult. Policy measures that target member countries more individually, such as the reduction of product and labor market frictions or price rigidities, are long-term measures and can therefore not be considered as adequate initial responses. It can thus be regarded as beneficial and favorable for both the individual EA member countries and the ECB to further reduce the influence of foreign shocks. This is especially true for the financial sector which, despite the overall reduction in the size of the responses, continues to be sensitive to foreign disruptions, potentially threatening EA financial stability. Hence, acting on the asymmetries reported here continues to be an important determinant of the EA's agenda in order to be better equipped for potential future disturbances. 


\section{References}

Andrews, Donald W.K. (1993). "Tests for parameter instability and structural change with unknown change point." Econometrica 61, 821-856.

Bai, Jushan and Ng, Serena. (2002). "Determining the number of factors in approximate factor models." Econometrica 70, 191-221.

Bai, Jushan and Ng, Serena. (2007). "Determining the Number of Primitive Shocks in Factor Models." Journal of Business \& Economic Statistics 25, 52-60.

Banerjee, Ryan, Devereux, Michael B. and Lombardo, Giovanni. (2016). "Self-oriented monetary policy, global financial markets and excess volatility of international capital flows." Journal of International Money and Finance 68, 275-297.

Barigozzi, Matteo, Conti, Antonio M. and Luciani, Matteo. (2014). "Do Euro area countries respond asymmetrically to the common monetary policy?" Oxford Bulletin of Economics and Statistics 76, 693-714.

Bauer, Michael D. and Rudebusch, Glenn D. (2016). "Monetary Policy Expectations at the Zero Lower Bound." Journal of Money, Credit and Banking 48, 1439-1465.

Bekaert, Geert, Hodrick, Robert J. and Zhang, Xiaoyan. (2009). "International stock return comovements." The Journal of Finance 64, 2591-2626.

Bekaert, Geert, Hoerova, Marie and Duca, Marco L. (2013). "Risk, uncertainty and monetary policy." Journal of Monetary Economics 60, 771-788.

Bernanke, Ben S. and Mihov, Ilian. (1998). "Measuring Monetary Policy". The Quarterly Journal of Economics 113, 869-902.

Bernanke, Ben. (2017). "Federal reserve policy in an international context." IMF Economic Review 65, 5-36.

Bjørnland, Hilde. C. and Halvorsen, Jørn. I.. (2014). "How does Monetary Policy Respond to Exchange Rate Movements? New International Evidence." Oxford Bulletinof Economics and Statistics 76, 208-232.

Bluedorn, John C. and Bowdler, Christopher. (2011). "The open economy consequences of US monetary policy." Journal of International Money and Finance 30, 309-336.

Boivin, Jean, Giannoni, Marc P. and Mojon, Benoît. (2008). "How has the Euro changed the monetary transmission?" NBER Working Paper 14190, National Bureau of Economic Research, July 2008.

Breitung, Jörg and Eickmeier, Sandra. (2011). "Testing for structural breaks in dynamic factor models." Journal of Econometrics 163, 71-84.

Bruno, Valentina and Shin, Hyun Song. (2015). "Capital flows and the risk-taking channel of monetary policy." Journal of Monetary Economics 71, 119-132.

Canova, Fabio. (2005). "The transmission of US shocks to Latin America." Journal of Applied Econometrics 20, 229-251. 
Conti, Antonio M., Neri, Stefano and Nobili, Andrea. (2015). "Why is inflation so low in the euro area?" Temi di discussione (Economic working papers), Bank of Italy, Economic Research and International Relations Area 1019, July 2015.

Conti, Antonio M. (2017). "Has the FED Fallen behind the Curve? Evidence from VAR models." Economics Letters 159, 164-168.

D'Agostino, Antonello and Giannone, Domenico. (2012). "Comparing Alternative Predictors Based on Large-Panel Factor Models." Oxford Bulletin of Economics and Statistics 74, 306326.

Dedola, Luca, Rivolta, Giulia and Stracca, Livio. (2017). "If the Fed sneezes, who catches a cold?" Journal of International Economics 108, 23-41.

Eickmeier, Sandra. (2007). "Business cycle transmission from the US to Germany - A structural factor approach." European Economic Review 51, 521-551.

Eickmeier, Sandra. (2009). "Comovements and heterogeneity in the euro area analyzed in a non-stationary dynamic factor model." Journal of Applied Econometrics 24, 933-959.

Eickmeier, Sandra and Hofmann, Boris. (2013). "Monetary policy, housing booms, and financial (Im)Balances." Macroeconomic Dynamics 17, 830-860.

Forni, Mario and Gambetti, Luca. (2010). "The dynamic effects of monetary policy: A structural factor model approach." Journal of Monetary Economics 57, 203-216.

Forni, Mario, Giannone, Domenico, Lippi, Marco and Reichlin, Lucrezia. (2009). "Opening the black box: Structural factor models with large cross sections." Econometric Theory 25, 1319-1347.

Fry, Renée and Pagan, Adrian. (2011). "Sign restrictions in structural vector autoregressions: A critical review." Journal of Economic Literature 49, 938-960.

Gambacorta, Leonardo, Hofmann, Boris and Peersman, Gert. (2014). "The effectiveness of unconventional monetary policy at the zero lower bound: A cross-country analysis." Journal of Money, Credit and Banking 46, 615-642.

Gambetti, Luca and Musso, Alberto. (2017). "Loan Supply Shocks and the Business Cycle." Journal of Applied Econometrics 32, 764-782.

Georgiadis, Georgios. (2015). "Examining asymmetries in the transmission of monetary policy in the euro area: Evidence from a mixed cross-section global VAR model." European Economic Review 75, 195-215.

Georgiadis, Georgios. (2016). "Determinants of global spillovers from US monetary policy." Journal of International Money and Finance 67, 41-61.

Georgiadis, Georgios. (2017). "To bi, or not to bi? Differences between spillover estimates from bilateral and multilateral multi-country models." Journal of International Economics 107, $1-18$.

Gertler, Mark and Karadi, Peter. (2015). "Monetary Policy Surprises, Credit Costs, and Economic Activity." American Economic Journal: Macroeconomics 7, 44-76. 
Giannone, Domenico, Reichlin, Lucrezia and Sala, Luca. (2005). "Monetary policy in real time." In NBER Macroeconomics Annual 2004, Volume 19, edited by Mark Gertler and Kenneth Rogoff, pp. 161-224. MIT Press.

Gilchrist, S., and Zakrajšek, E. (2012). "Credit spreads and business cycle fluctuations." American Economic Review, 102, 1692-1720.

Hallin, Mark and Liska, Roman. (2007). "Determining the number of factors in the general dynamic factor model." Journal of the American Statistical Association 102, 603-617.

Hanisch, Max. (2017). "The effectiveness of conventional and unconventional monetary policy: evidence from a structural dynamic factor model for Japan." Journal of International Money and Finance 70, 110-134.

Hanisch, Max and Kempa, Bernd. (2017). "The international transmission channels of US supply and demand shocks: Evidence from a non-stationary dynamic factor model for the G7 countries." The North American Journal of Economics and Finance 42, 70-88.

Ilzetzki, Ethan, Reinhart, Carmen M. and Rogoff, Kenneth S. (2017). "Exchange Arrangements Entering the 21st Century: Which Anchor Will Hold?" NBER Working Paper 23134, National Bureau of Economic Research, February 2017.

Inklaar, Robert, Jong-A-Pin, Richard and de Haan, Jakob. (2008). "Trade and business cycle synchronization in OECD countries - A re-examination." European Economic Review 52, 646-666.

Kilian, Lutz. (1998). "Small-sample confidence intervals for impulse response functions." Review of Economics and Statistics 80, 218-230.

Kim, Soyoung. (1999). "Do monetary policy shocks matter in the G-7 countries? Using common identifying assumptions about monetary policy across countries." Journal of International Economics 48, 387-412.

Kim, Soyoung, Roubini, Nouriel. (2000). "Exchange rate anomalies in the industrial countries: A solution with a structural VAR approach." Journal of Monetary Economics 45, 561-586.

Luciani, Matteo. (2015). "Monetary Policy and the Housing Market: A Structural Factor Analysis." Journal of Applied Econometrics 30, 199-218.

Maćkowiak, Bartosz. (2007). "External shocks, US monetary policy and macroeconomic fluctuations in emerging markets." Journal of Monetary Economics 54, 2512-2520.

Miranda-Agrippino, Silvia and Rey, Hélène. (2015). "World asset markets and the global financial cycle." NBER Working Paper 21722, National Bureau of Economic Research, November 2015 .

Musso, Alberto, Neri, Stefano and Stracca, Livio. (2011). "Housing, consumption and monetary policy: How different are the US and the euro area?" Journal of Banking \& Finance 35, 30193041.

Neri, Stefano and Nobili, Andrea. (2010). "The Transmission of US Monetary Policy to the Euro Area."International Finance 13, 55-78. 
Peersman, Gert. (2004). "The Transmission of Monetary Policy in the Euro Area: Are the Effects Different Across Countries?" Oxford Bulletin of Economics and Statistics 66, 285308.

Rey, Hélène. (2015). "Dilemma not trilemma: the global cycle and monetary policy independence." NBER Working Paper 21162, National Bureau of Economic Research, May 2015.

Stock, James H. and Watson, Mark W.. (2002). "Forecasting using principal components from a large number of predictors." Journal of the American Statistical Association 97, 1167-1179.

Stock, James H. and Watson, Mark W.. (2005). "Implications of dynamic factor models for VAR analysis." NBER Working Paper 11467, National Bureau of Economic Research, June 2005.

Swanson, Eric T. and Williams, John C.. (2014). "Measuring the effect of the zero lower bound on medium-and longer-term interest rates." The American Economic Review 104, 3154-3185.

Uhlig, Harald. (2005). "What are the effects of monetary policy on output? Results from an agnostic identification procedure." Journal of Monetary Economics 52, 381-419.

von Borstel, Julia, Sandra Eickmeier, and Leo Krippner. (2016). "The interest rate passthrough in the euro area during the sovereign debt crisis." Journal of International Money and Finance 68, 386-402.

Wu, Jing Cynthia and Xia, Fan Dora. (2016). "Measuring the Macroeconomic Impact of Monetary Policy at the Zero Lower Bound." Journal of Money, Credit and Banking 48, 253-291. 


\section{Tables}

Table 1: Breitung and Eickmeier (2011) test results

\begin{tabular}{lllccccccc}
\hline & GER & FR & NL & IT & ESP & IRE & BEL & FIN & POR \\
\hline Gross Domestic Product & 94.18 & 94.77 & 78.31 & 105.04 & 111.98 & 60.40 & 97.45 & 55.07 & 76.63 \\
Consumer Price Index & 93.48 & 109.71 & 75.88 & 113.90 & 102.35 & 87.16 & 98.61 & 75.35 & 108.22 \\
Private Consumption & 59.96 & 80.11 & 60.89 & 82.92 & 97.56 & & & & \\
Investment & 70.89 & 77.35 & 46.25 & 78.83 & 86.38 & & & & \\
Nominal Exchange Rate & 109.63 & 105.94 & 109.41 & 94.95 & 100.94 & & & & \\
Real Exchange Rate & 77.94 & 71.28 & 90.74 & 58.46 & 73.61 & & & & \\
\hline
\end{tabular}

Results of the Breitung and Eickmeier (2011) test for a breakpoint in the factor loadings.

Note: Table shows the LM statistic for the null hypothesis of no structural break in the factor loadings on the 1st of January 1999. The $10 \%, 5 \%$ and $1 \%$ critical values with $r$ degrees of freedom are $13.35,15.51$ and 20.09 respectively, as provided by Andrews (1993). 
Table 2: Benchmark model sign restrictions

\begin{tabular}{lcc}
\hline US Variables & $>/<$ & $h$ \\
\hline Augm. FFR & $>0$ & $0-2$ \\
2-Year GB & $>0$ & 0 \\
Gross Domestic Product & $<0$ & $0-2$ \\
Consumer Price Index & $<0$ & $0-2$ \\
GDP Deflator & $<0$ & $0-2$ \\
M1 & $<0$ & $0-2$ \\
Diff & $<0$ & 0 \\
\hline
\end{tabular}

Note: sign restrictions for th contractionary US monetary policy shock. First column of each variable indicates the dictated sign. Second column of each variable indicates the number of horizons $h$ for which the sign restriction is imposed, where $h=0$ is the impact response. 
Table 3: Number of static factors

\begin{tabular}{lccr}
\hline $\mathrm{r}$ & $\mu_{i}^{x}$ & $I C_{1}$ & $P C_{1}$ \\
\hline 1 & 0.2329 & -0.2199 & 0.7746 \\
2 & 0.1108 & -0.3227 & 0.6783 \\
3 & 0.0650 & -0.3738 & 0.6274 \\
4 & 0.0571 & -0.4221 & 0.5843 \\
5 & 0.0473 & -0.4617 & 0.5509 \\
6 & 0.0311 & -0.4745 & 0.5337 \\
7 & 0.0251 & -0.4760 & 0.5224 \\
8 & 0.0215 & -0.4779 & 0.5145 \\
9 & 0.0194 & -0.4715 & 0.5088 \\
10 & 0.0161 & -0.4604 & 0.5065 \\
11 & 0.0157 & -0.4503 & 0.5044 \\
12 & 0.0148 & -0.4394 & 0.5033 \\
13 & 0.0131 & -0.4251 & 0.5038 \\
14 & 0.0120 & -0.4089 & 0.5055 \\
\hline
\end{tabular}

Note: $\mu_{i}^{x}$ is the percentage share of the variance covariance matrix of $x$ explained by the $i$-th eigenvalue (in decreasing order). IC 1 and $P C_{1}$ are the Bai and $\mathrm{Ng}$ (2002) criteria allowing for $r_{\max }=20$ static factors. 
Table 4: Cumulated explained variance

\begin{tabular}{|c|c|c|c|c|c|c|c|c|c|c|c|c|}
\hline & 1 & 2 & 3 & 4 & 5 & 6 & 7 & 8 & 9 & 10 & 11 & 12 \\
\hline$r$ & 0.23 & 0.34 & 0.41 & 0.47 & 0.51 & 0.55 & 0.57 & 0.59 & 0.62 & 0.64 & 0.66 & 0.67 \\
\hline$q$ & 0.30 & 0.45 & 0.54 & 0.61 & 0.66 & 0.71 & 0.75 & 0.78 & 0.80 & 0.82 & 0.87 & 0.88 \\
\hline
\end{tabular}


Table 5: Explained variance

\begin{tabular}{lclc}
\hline Variable & $\%$ & Variable & $\%$ \\
\hline US: Gross Domestic Product & 0.5728 & Netherlands: Gross Domestic Product & 0.3296 \\
US: Consumer Price Index & 0.6505 & Netherlands: Consumer Price Index & 0.5827 \\
US: Policy Interest Rate & 0.8733 & Netherlands: Policy Interest Rate & 0.8993 \\
US: Real Effective Ex. Rate & 0.9113 & Netherlands: Real Effective Ex. Rate & 0.8155 \\
Germany: Gross Domestic Product & 0.6357 & Italy: Gross Domestic Product & 0.6294 \\
Germany: Consumer Price Index & 0.7653 & Italy: Consumer Price Index & 0.9195 \\
Germany: Policy Interest Rate & 0.8368 & Italy: Policy Interest Rate & 0.9726 \\
Germany: Real Effective Ex. Rate & 0.7409 & Italy: Real Effective Ex. Rate & 0.6897 \\
France: Gross Domestic Product & 0.7756 & Spain: Gross Domestic Product & 0.5347 \\
France: Consumer Price Index & 0.8893 & Spain: Consumer Price Index & 0.7797 \\
France: Real Effective Ex. Rate & 0.7585 & Spain: Policy Interest Rate & 0.9447 \\
France: Policy Interest Rate & 0.9685 & Spain: Real Effective Ex. Rate & 0.8643 \\
\hline
\end{tabular}

Note: Share of explained variance accounted for by the common component over the full sample for selected key variables. 
Table 6: Variations on the identification scheme

\begin{tabular}{|c|c|c|c|c|c|c|c|c|c|c|}
\hline \multirow[b]{2}{*}{ US Variable } & \multicolumn{2}{|c|}{$\mathrm{I}$} & \multicolumn{2}{|c|}{ II } & \multicolumn{2}{|c|}{ III } & \multicolumn{2}{|c|}{ IV } & \multicolumn{2}{|c|}{$\mathrm{V}$} \\
\hline & $\geq / \leq$ & $h$ & $\geq / \leq$ & $h$ & $\geq / \leq$ & $h$ & $\geq / \leq$ & $h$ & $\geq / \leq$ & $h$ \\
\hline Augm. FFR & $\geq 0$ & $0-2$ & $\geq 0$ & $0-2$ & $\geq 0$ & $0-2$ & $\geq 0$ & 0 & $\geq 0$ & 0 \\
\hline 2-Year GB & $\geq 0$ & 0 & $\geq 0$ & 0 & $\geq 0$ & 0 & $\geq 0$ & 0 & $\geq 0$ & 0 \\
\hline Gross Domestic Product & $\leq 0$ & $0-2$ & & & $\leq 0$ & $0-2$ & & & $=0$ & 0 \\
\hline Consumer Price Index & $\leq 0$ & $0-2$ & $\leq 0$ & $0-2$ & & & $\leq 0$ & 4 & $=0$ & 0 \\
\hline GDP Deflator & $\leq 0$ & $0-2$ & $\leq 0$ & $0-2$ & & & & & $=0$ & 0 \\
\hline M1 & $\leq 0$ & $0-2$ & $\leq 0$ & $0-2$ & $\leq 0$ & $0-2$ & & & $\leq 0$ & 0 \\
\hline $\operatorname{Diff}_{I n t R}$ & $\leq 0$ & 0 & $\leq 0$ & 0 & $\leq 0$ & 0 & $\leq 0$ & 0 & $\leq 0$ & 0 \\
\hline Real Effective Ex. Rate & $\geq 0$ & 0 & & & & & & & & \\
\hline World Oil Price & & & & & $\leq 0$ & $0-2$ & & & & \\
\hline
\end{tabular}

Note: first column of each identification scheme indicates the dictated signs. Second column of each identification scheme indicates the number of horizons $h$, for which the sign restrictions are imposed where $h=0$ is the impact response. 


\section{Figures}
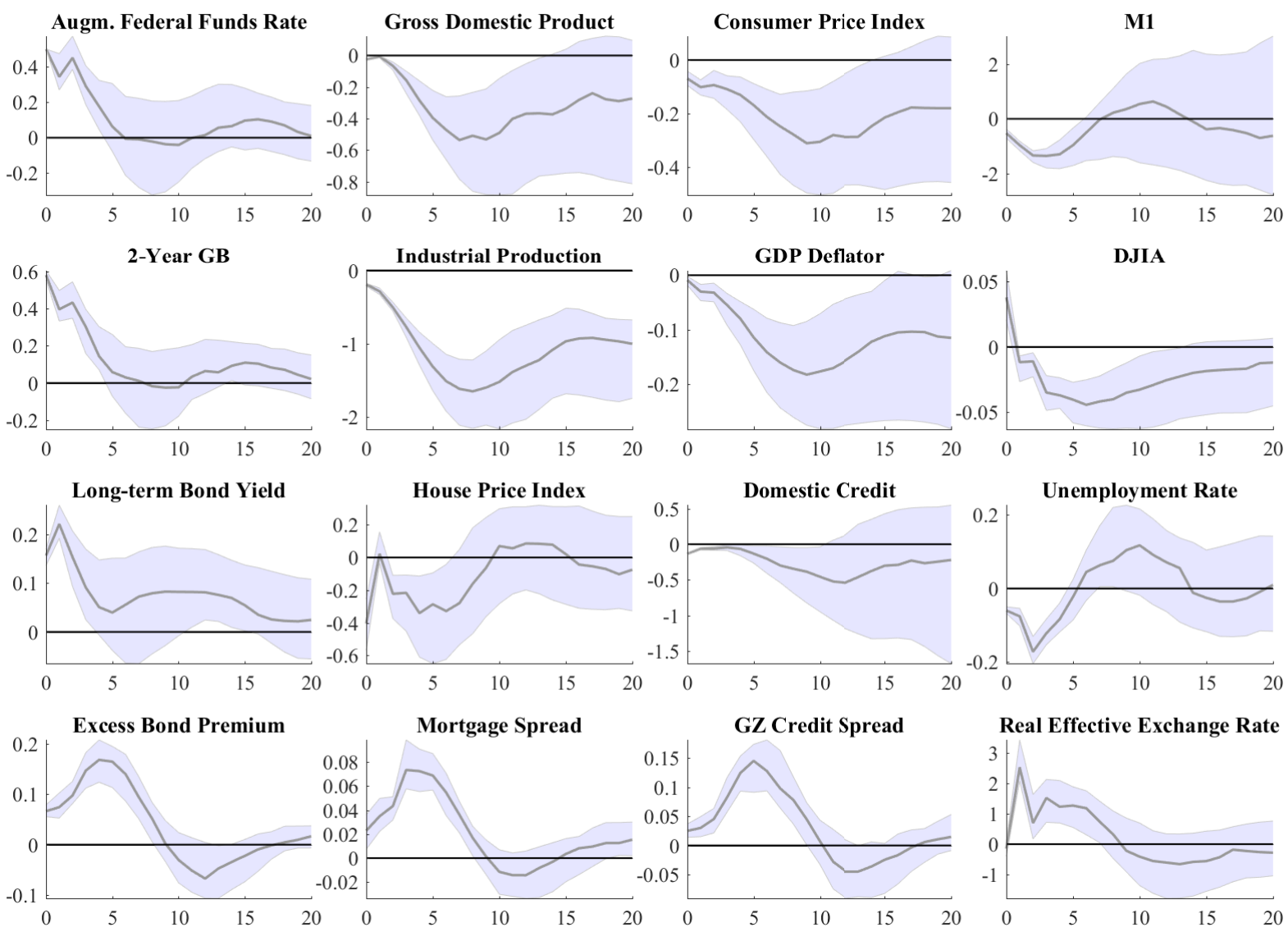

Figure 1: Impulse responses to a contractionary US monetary policy shock: US variables (in \%), where the augmented Federal Funds Rate incorporates the shadow Federal Funds rate as proposed by Wu and Xia (2016).

Solid grey lines indicate the estimated median impulse responses over the full sample with $68 \%$ confidence bands (shaded areas). 

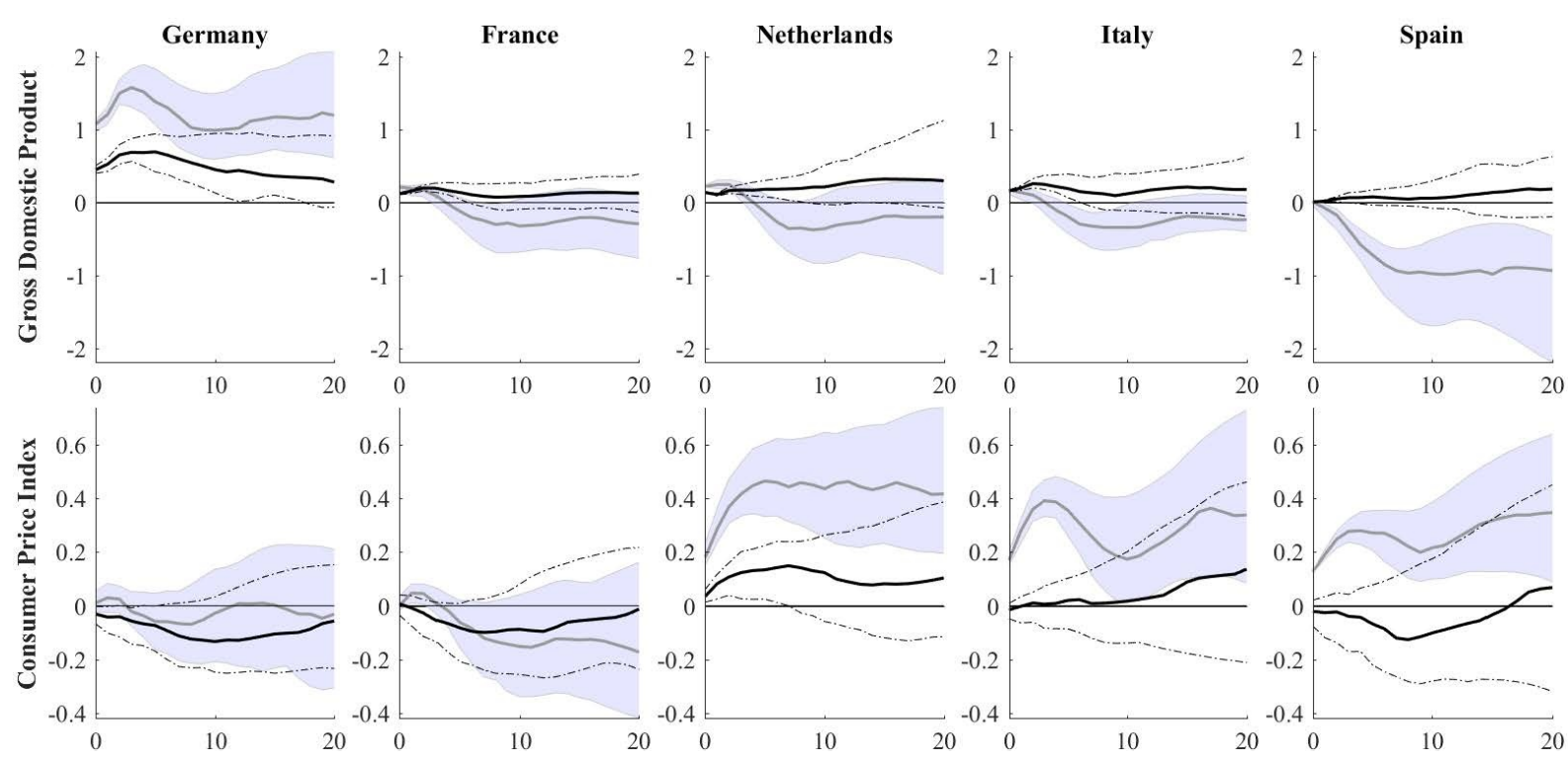

Figure 2: Impulse responses to a contractionary US monetary policy shock: EA output and inflation (in \%).

Solid grey lines indicate the estimated median impulse responses for the 1983.I-1998.IV period with $68 \%$ confidence bands (shaded areas). Solid black lines indicate the estimated median impulse responses for the 1999.I-2015.I period with $68 \%$ confidence bands (dashdotted lines). 

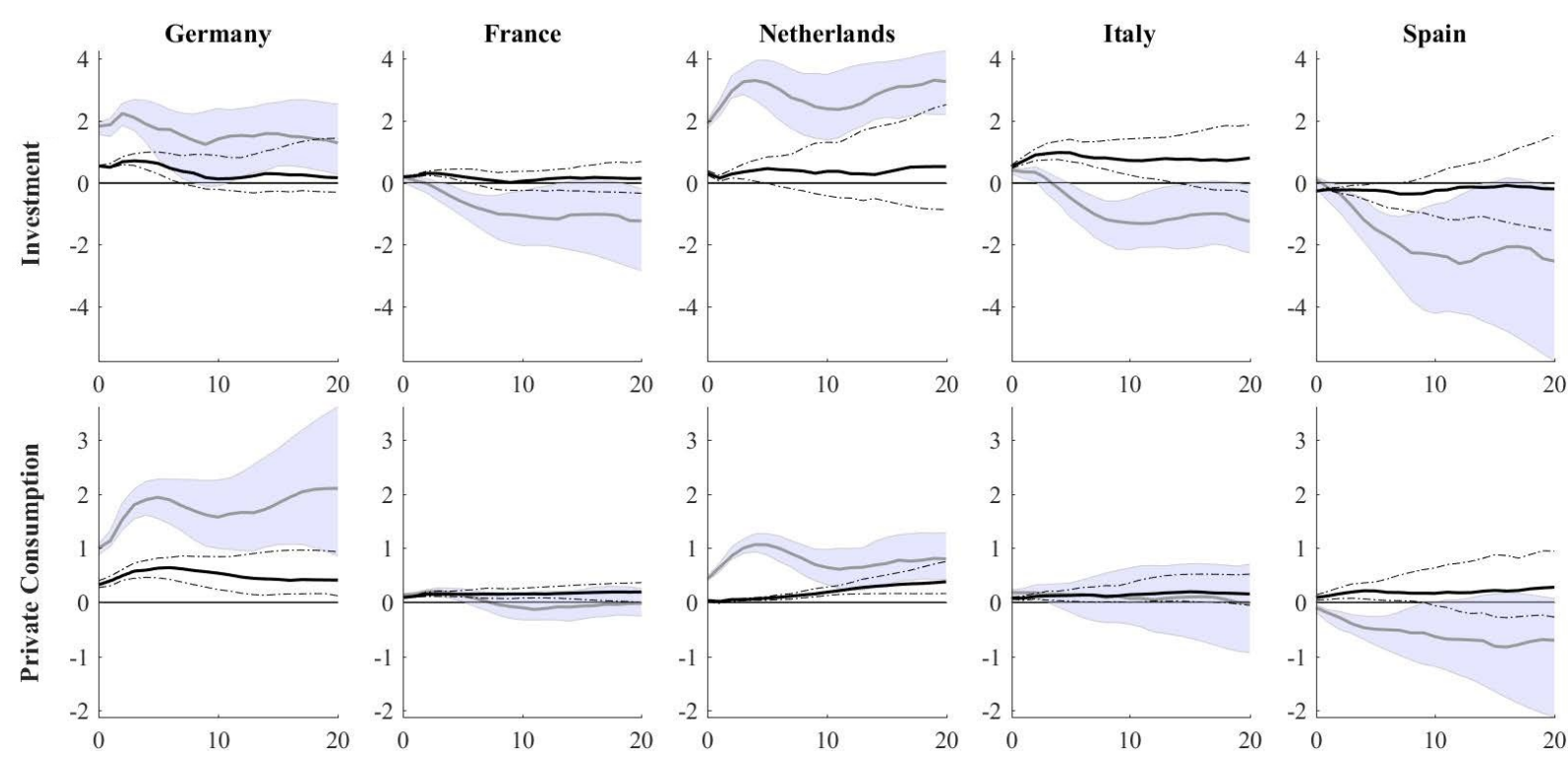

Figure 3: Impulse responses to a contractionary US monetary policy shock: EA investment and private consumption (in \%).

Solid grey lines indicate the estimated median impulse responses for the 1983.I-1998.IV period with $68 \%$ confidence bands (shaded areas). Solid black lines indicate the estimated median impulse responses for the 1999.I-2015.I period with $68 \%$ confidence bands (dashdotted lines). 

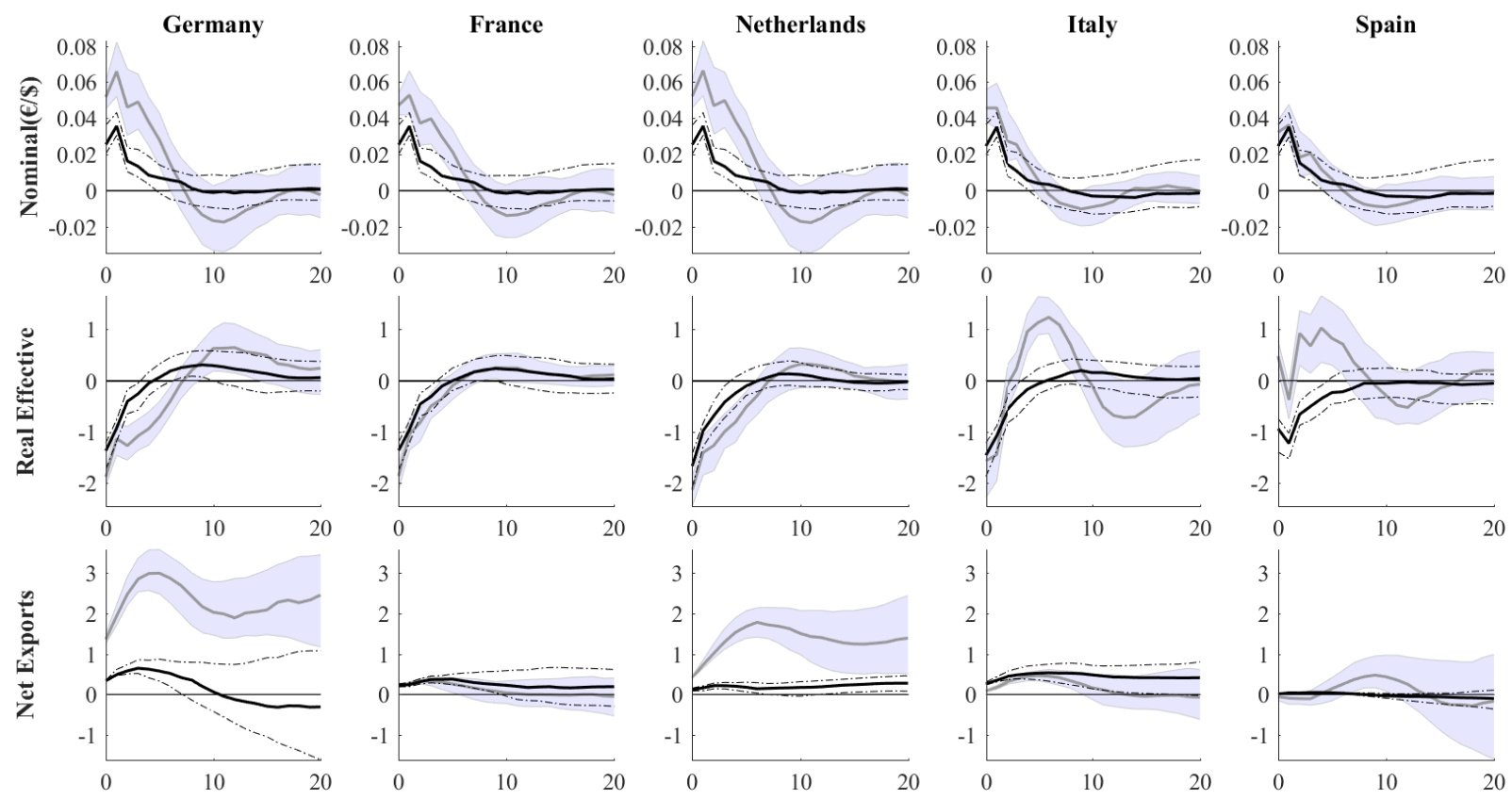

Figure 4: Impulse responses to a contractionary US monetary policy shock: EA exchange rates and net exports (in \% except for nominal exchange rates, which are in $€ / \$$; net exports are constructed manually as Exports minus Imports).

Solid grey lines indicate the estimated median impulse responses for the 1983.I-1998.IV period with $68 \%$ confidence bands (shaded areas). Solid black lines indicate the estimated median impulse responses for the 1999.I-2015.I period with $68 \%$ confidence bands (dashdotted lines). 

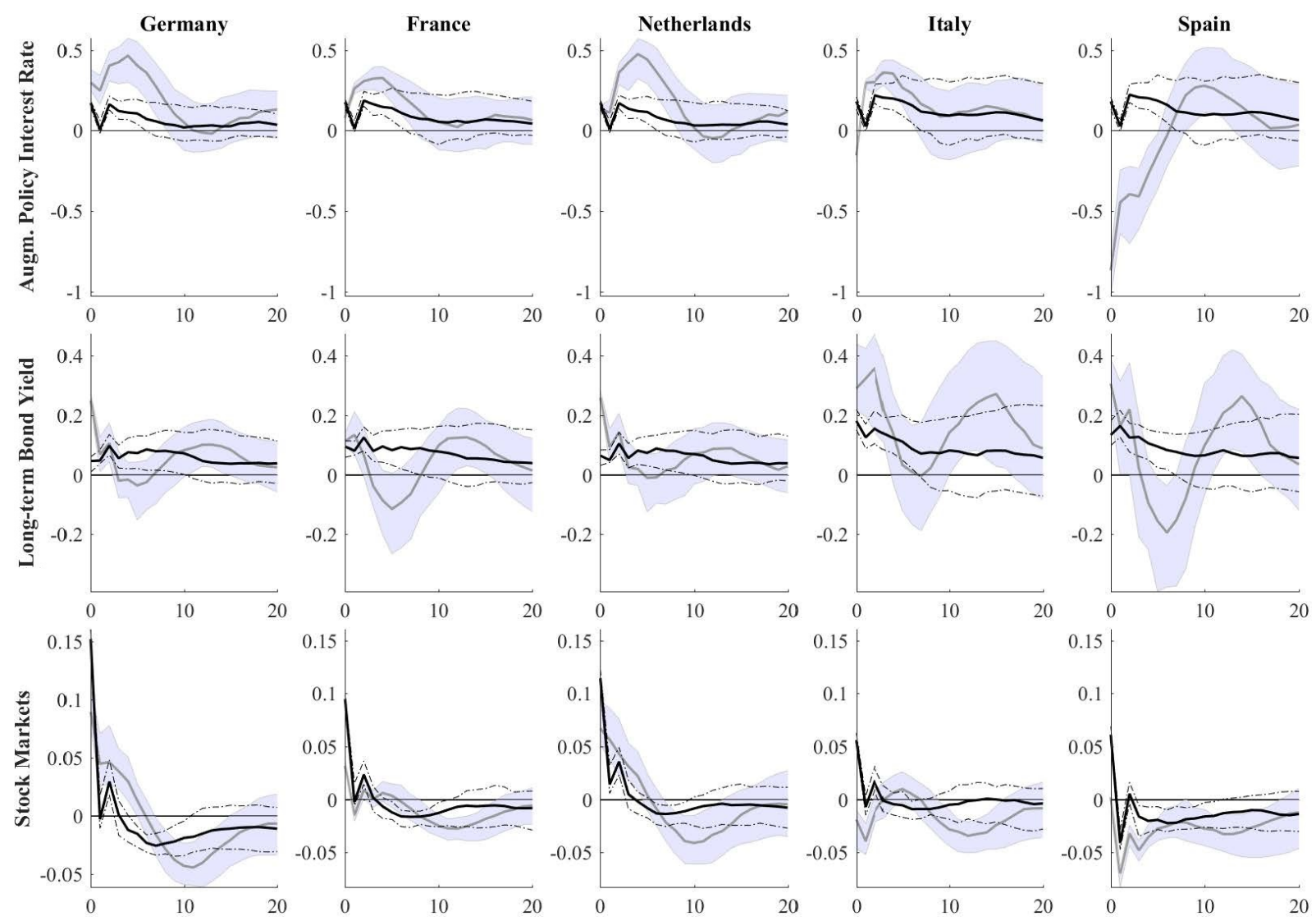

Figure 5: Impulse responses to a contractionary US monetary policy shock: EA interest rates and stock markets (in \%), where the augmented Policy Rate incorporates the ECB shadow rate as proposed by $\mathrm{Wu}$ and Xia (2016).

Solid grey lines indicate the estimated median impulse responses for the 1983.I-1998.IV period with $68 \%$ confidence bands (shaded areas). Solid black lines indicate the estimated median impulse responses for the 1999.I-2015.I period with $68 \%$ confidence bands (dashdotted lines). 

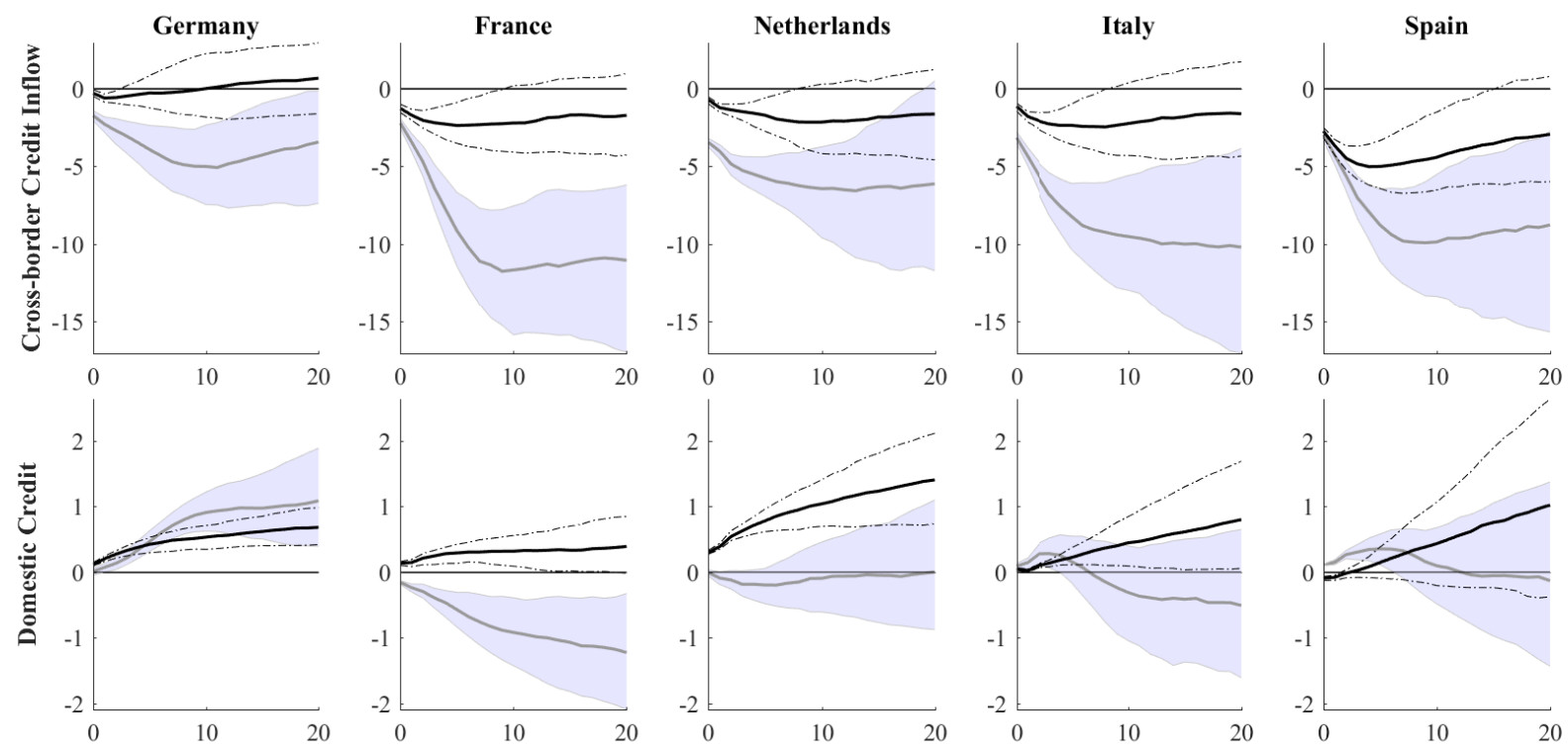

Figure 6: Impulse responses to a contractionary US monetary policy shock: EA credit markets (in \%). Solid grey lines indicate the estimated median impulse responses for the 1983.I-1998.IV period with $68 \%$ confidence bands (shaded areas). Solid black lines indicate the estimated median impulse responses for the 1999.I-2015.I period with $68 \%$ confidence bands (dashdotted lines). 

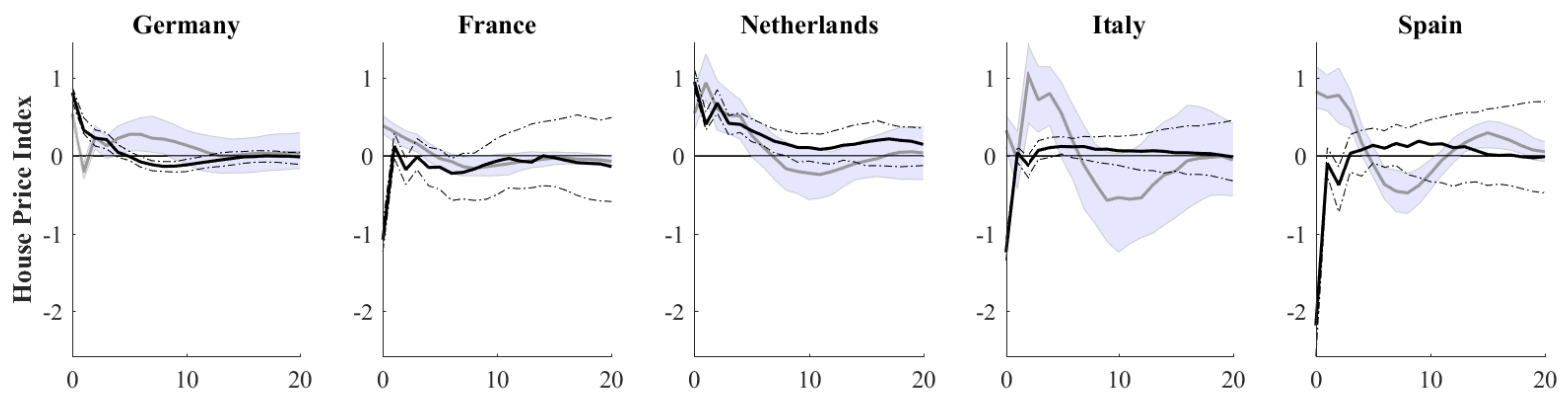

Figure 7: Impulse responses to a contractionary US monetary policy shock: EA house price indices (in \%).

Solid grey lines indicate the estimated median impulse responses for the 1983.I-1998.IV period with $68 \%$ confidence bands (shaded areas). Solid black lines indicate the estimated median impulse responses for the 1999.I-2015.I period with $68 \%$ confidence bands (dashdotted lines). 

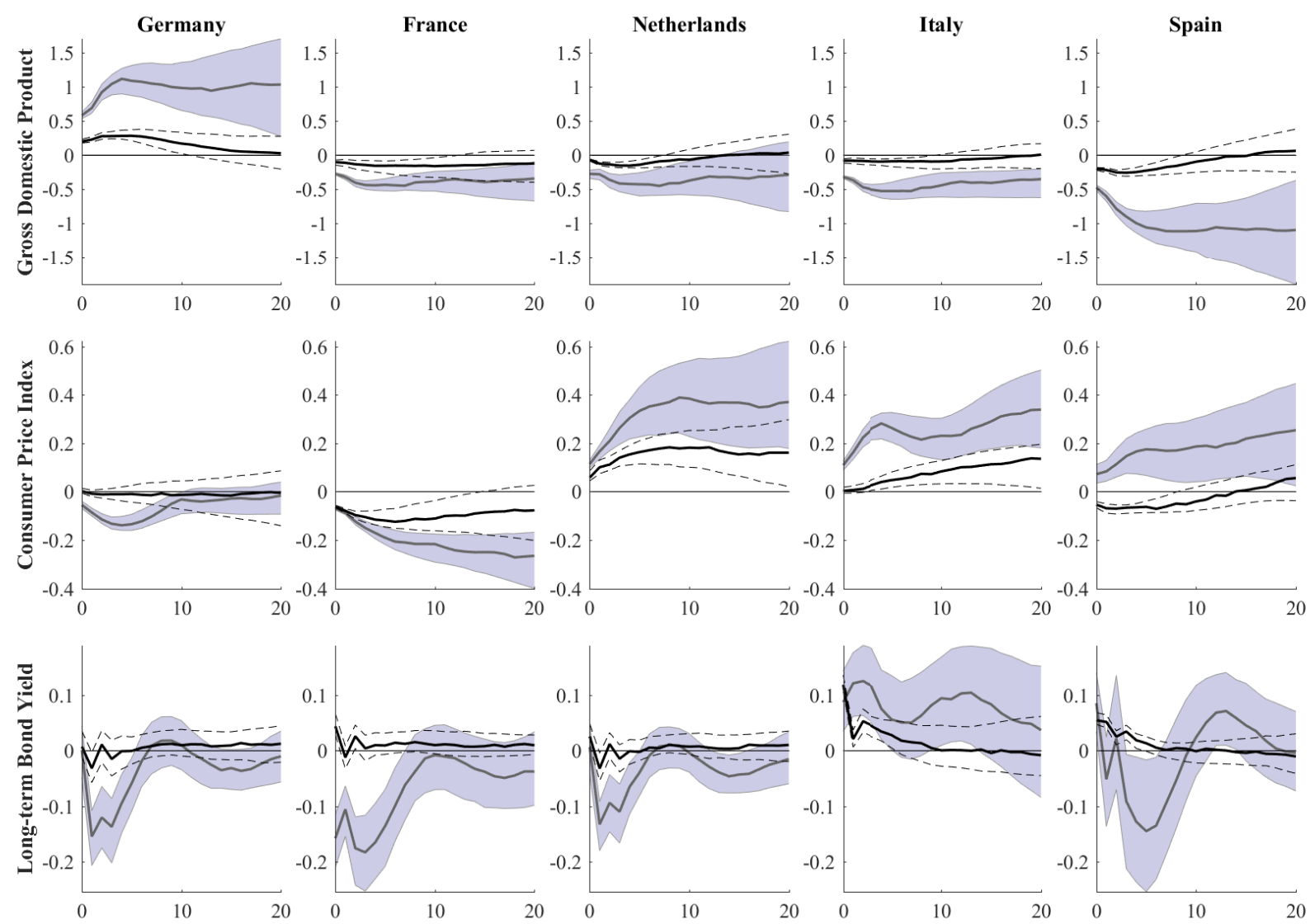

Figure 8: Testing cross-country asymmetries.

Solid grey lines indicate the estimated median difference to the aggregate EA-wide response of the same variable for the 1983.I-1998.IV period with $68 \%$ confidence bands (dark shaded areas). Solid black lines indicate the estimated median difference to the aggregate EA-wide response of the same variable for the 1999.I-2015.I period with $68 \%$ confidence bands (dashed lines). 


\section{Appendix}

\section{A Details on data and transformation}

Table A.1: Data description and treatment

\begin{tabular}{|c|c|c|c|c|c|c|c|}
\hline No. & Name & $\mathrm{C}$ & $\mathrm{F}$ & SA & Unit & $\mathrm{T}$ & Series ID \\
\hline \multicolumn{8}{|c|}{$U S$} \\
\hline 1 & GDP (real) & 1 & $\mathrm{Q}$ & 1 & 2010BilUS\$ & 3 & USGDP...D \\
\hline 2 & GFCF (real) & 1 & $\mathrm{Q}$ & 1 & 2010BilUS\$ & 3 & USOEXO04D \\
\hline 3 & Government Consumption Expenditure (real) & 1 & $\mathrm{Q}$ & 1 & 2009BilUS\$ & 3 & USCNGOV.D \\
\hline 4 & Total Retail Trade (Value) & 1 & $\mathrm{Q}$ & 1 & $2010=100$ & 3 & USQSLIO7E \\
\hline 5 & Industrial Production (Volume) & 1 & $\mathrm{Q}$ & 1 & $2010=100$ & 3 & USQ66..CE \\
\hline 6 & Capacity Utilization, Total & 1 & $\mathrm{M}$ & 1 & $\%$ & 1 & USCAPUTLQ \\
\hline 7 & Consumer Price Index, All Items & 2 & M & 1 & $1984=100$ & 3 & USCONPRCE \\
\hline 8 & Core Consumer Price Index & 2 & $\mathrm{M}$ & 1 & $1982-1984=100$ & 3 & USCPCOREE \\
\hline 9 & Consumer Price Index, Energy & 2 & $\mathrm{Q}$ & 0 & $1982-1984=100$ & 3 & USQCP041F \\
\hline 10 & Producer Price Index, Final Demand & 2 & $\mathrm{Q}$ & 1 & $2009 \mathrm{M} 11=100$ & 3 & USQCP041F \\
\hline 11 & GDP Deflator & 2 & $\mathrm{Q}$ & 1 & $2010=100$ & 3 & USQNA057E \\
\hline 12 & House Price Index & 2 & $\mathrm{Q}$ & 1 & $1991 \mathrm{Q} 1=100$ & 3 & USXPHI..E \\
\hline 13 & Personal Consumption Expenditure (real) & 3 & $\mathrm{Q}$ & 1 & 2009BilUS $\$$ & 3 & USCNPER.D \\
\hline 14 & Personal Disposable Income (real) & 3 & $\mathrm{Q}$ & 1 & 2009BilUS $\$$ & 3 & USPDISPID \\
\hline 15 & Hourly Earnings, Manufacturing & 3 & $\mathrm{Q}$ & 1 & $2010=100$ & 3 & USQLC007E \\
\hline 16 & Employment, Total & 4 & $\mathrm{M}$ & 1 & Thous. & 3 & USEMPTOTO \\
\hline 17 & Unemployment Rate & 4 & M & 1 & $\%$ & 1 & USUN\%TOTQ \\
\hline 18 & Unit Wage Costs, Whole Economy & 4 & $\mathrm{Q}$ & 1 & $2008=100$ & 3 & USXWCU..E \\
\hline 19 & Unit Wage Costs, Manufacturing & 4 & $\mathrm{Q}$ & 1 & $2008=100$ & 3 & USXWCMF.E \\
\hline 20 & Money Supply M1 & 5 & M & 1 & BilUS\$ & 3 & USM1.... B \\
\hline 21 & Money Supply M3 & 5 & M & 1 & $2010=100$ & 3 & USOMA001G \\
\hline 22 & St. Louis Adjusted Reserves & 5 & $\mathrm{M}$ & 0 & BilUS\$ & 3 & ADJRESNS \\
\hline 23 & Policy Rate*: Federal Funds Target Rate & 6 & M & 0 & $\%$ & 1 & USOMA001G \\
\hline 24 & London Interbank Offered Rate, 3 Month & 6 & M & 0 & $\%$ & 1 & USINTER3 \\
\hline 25 & US 2-Year Treasury Constant Maturity Rate & 6 & M & 0 & $\%$ & 1 & DGS2 \\
\hline 26 & Long-term Treasury Yield & 6 & $\mathrm{M}$ & 0 & $\%$ & 1 & USGBOND. \\
\hline 27 & Dow Jones, Averages, Industrial Index & 7 & M & 0 & Index & 3 & USSHRPRCF \\
\hline 28 & Excess Bond Premium & 7 & $\mathrm{M}$ & 0 & Index & 1 & \\
\hline 29 & Mortgage Spread & 7 & M & 0 & Index & 1 & \\
\hline 30 & Credit Spread & 7 & $\mathrm{M}$ & 0 & Index & 1 & \\
\hline 31 & Credit to private nonfinancial sectors from all sectors & 7 & $\mathrm{Q}$ & 0 & BilUS\$ & 3 & USBLCAPAA \\
\hline 32 & Cross-border credit positions reported by banking offices & 7 & $\mathrm{Q}$ & 0 & MilUS\$ & 3 & \\
\hline 33 & OECD Industrial Confidence Indicator & 7 & M & 1 & Actual & 3 & USOBS085Q \\
\hline 34 & Composite Leading Indicator & 7 & $\mathrm{M}$ & 1 & Actual & 3 & USCYLEADT \\
\hline 35 & Competitiveness Indicator, Relative Unit Labour Costs & 7 & $\mathrm{Q}$ & 1 & $2010=100$ & 3 & USOCFCDRE \\
\hline 36 & Exports, Goods \& Services, Total (real) & 8 & $\mathrm{Q}$ & 1 & 2009BilUS\$ & 3 & USEXNGS.D \\
\hline 37 & Imports, Goods \& Services, Total (real) & 8 & $\mathrm{Q}$ & 1 & 2009BilUS\$ & 3 & USIMNGS.D \\
\hline 38 & Nominal Exchange Rate: $€ / \$$ & 8 & $\mathrm{Q}$ & $\mathrm{n} / \mathrm{a}$ & $€$ & 1 & USX\$EURQ \\
\hline 39 & Real Effective Exchange Rate, Consumer Price Index Based & 8 & $\mathrm{Q}$ & 0 & $2010=100$ & 1 & USQCC011H \\
\hline 40 & Terms Of Trade & 8 & M & 0 & $1975=100$ & 3 & USTOTPRCF \\
\hline \multicolumn{8}{|c|}{ Germany } \\
\hline 41 & GDP (real) & 1 & $\mathrm{Q}$ & 1 & $2010 \mathrm{Mil} €$ & 3 & BDOEXO03D \\
\hline 42 & GFCF (real) & 1 & $\mathrm{Q}$ & 1 & $2010 \mathrm{Mil} €$ & 3 & BDOEXO04D \\
\hline 43 & Government Consumption Expenditure (real) & 1 & $\mathrm{Q}$ & 1 & $2010 \mathrm{Bil} €$ & 3 & BDXGCR..D \\
\hline 44 & Total Retail Trade (Value) & 1 & $\mathrm{Q}$ & 1 & $2010=100$ & 3 & BDQSLIO7E \\
\hline 45 & Industrial Production (Volume) & 1 & $\mathrm{Q}$ & 1 & $2010=100$ & 3 & BDQ66..CE \\
\hline 46 & Capacity Utilization, Total & 1 & $\mathrm{Q}$ & 1 & $\%$ & 1 & BDIFDMT.Q \\
\hline 47 & Consumer Price Index, All Items & 2 & $\mathrm{M}$ & 0 & $2010=100$ & 3 & BDCONPRCF \\
\hline 48 & Core Consumer Price Index & 2 & $\mathrm{Q}$ & 0 & $2010=100$ & 3 & $\mathrm{BDQCP} 042 \mathrm{~F}$ \\
\hline 49 & Consumer Price Index, Energy & 2 & $\mathrm{Q}$ & 0 & $2010=100$ & 3 & $\mathrm{BDQCP} 041 \mathrm{~F}$ \\
\hline 50 & Producer Price Index, Total Industry & 2 & M & 0 & $2010=100$ & 3 & BDPROPRCF \\
\hline 51 & GDP Deflator & 2 & $\mathrm{Q}$ & 1 & $2010=100$ & 3 & BDQNA057E \\
\hline 52 & House Price Index & 2 & $\mathrm{Q}$ & 0 & $2005 \mathrm{M} 8=100$ & 3 & BDXPHI..F \\
\hline 53 & Personal Consumption Expenditure (real) & 3 & $\mathrm{Q}$ & 1 & $2010 \mathrm{Mil} €$ & 3 & BDOEXO06D \\
\hline 54 & Personal Disposable Income (real) & 3 & $\mathrm{Q}$ & 0 & 2010Bil€ & 3 & BDXPEDY.C \\
\hline 55 & Hourly Earnings, Manufacturing & 3 & $\mathrm{Q}$ & 1 & $2010=100$ & 3 & BDOLC007E \\
\hline 56 & Employment, Total & 4 & $\mathrm{Q}$ & 1 & Thous. & 3 & BDQLFT12O \\
\hline 57 & Unemployment Rate & 4 & M & 0 & $\%$ & 1 & BDUN\%TOTR \\
\hline 58 & Unit Wage Costs, Whole Economy & 4 & $\mathrm{Q}$ & 0 & $2008=100$ & 3 & BDXWCU..F \\
\hline 59 & Unit Wage Costs, Manufacturing & 4 & $\mathrm{Q}$ & 0 & $2008=100$ & 3 & BDXWCMF.F \\
\hline 60 & Money Supply M1 & 5 & $\mathrm{M}$ & 0 & Bil€ & 3 & $\mathrm{BDM} 1 \ldots \mathrm{A}$ \\
\hline 61 & Money Supply M3 (Contribution to Euro Basis) & 5 & $\mathrm{M}$ & 1 & Bil€ & 3 & BDM3.... B \\
\hline 62 & Policy Rate*: Discount Rate / Short-term Euro Repo Rate & 6 & $\mathrm{M}$ & 0 & $\%$ & 1 & BDPRATE. \\
\hline 63 & Frankfurt Interbank Offered Rate, 3 Month & 6 & M & 0 & $\%$ & 1 & BDINTER3 \\
\hline 64 & Long-term Government Bond Yield & 6 & M & 0 & $\%$ & 1 & BDGBOND. \\
\hline 65 & Deutsche Boerse, DAX 30 & 7 & $\mathrm{M}$ & 0 & Index & 3 & BDSHRPRCF \\
\hline 66 & Credit to private nonfinancial sectors from all sectors & 7 & $\mathrm{Q}$ & 0 & Bil€ & 3 & BDBLCAPAA \\
\hline 67 & Cross-border credit positions reported by banking offices & 7 & $\mathrm{Q}$ & 0 & Mil\$ & 3 & \\
\hline 68 & OECD Industrial Confidence Indicator & 7 & M & 1 & Actual & 3 & BDOBS085Q \\
\hline 69 & Composite Leading Indicator & 7 & $\mathrm{M}$ & 1 & Actual & 3 & BDCYLEADT \\
\hline 70 & Competitiveness Indicator, Relative Unit Labour Costs & 7 & $\mathrm{Q}$ & 1 & $2010=100$ & 3 & BDOCFCDRE \\
\hline 71 & Exports, Goods \& Services, Total (real) & 8 & $\mathrm{Q}$ & 1 & $2010 \mathrm{Mil} €$ & 3 & BDOEXO01D \\
\hline 72 & Imports, Goods \& Services, Total (real) & 8 & $\mathrm{Q}$ & 1 & $2010 \mathrm{Mil} €$ & 3 & BDOEXO05D \\
\hline
\end{tabular}


Table A.1: Data description and treatment (continued)

\begin{tabular}{|c|c|c|c|c|c|c|c|}
\hline No. & Name & $\mathrm{C}$ & $\mathrm{F}$ & SA & Unit & $\mathrm{T}$ & Series ID \\
\hline \multicolumn{8}{|c|}{ Germany (continued) } \\
\hline 73 & Nominal Exchange Rate: DEM- $€ / \$$ & 8 & $\mathrm{Q}$ & 1 & $€$ & 1 & BDQCC015P \\
\hline 74 & Real Effective Exchange Rate, Consumer Price Index Based & 8 & $\mathrm{Q}$ & 0 & $2010=100$ & 1 & $\mathrm{BDQCC011H}$ \\
\hline 75 & Terms Of Trade & 8 & M & 0 & $2010=100$ & 3 & BDTOTPRCF \\
\hline \multicolumn{8}{|c|}{ France } \\
\hline 76 & GDP (real) & 1 & $\mathrm{Q}$ & 1 & 2010Bil€ & 3 & FRGDP...D \\
\hline 77 & GFCF (real) & 1 & $\mathrm{Q}$ & 1 & $2010 \mathrm{Mil} €$ & 3 & FRGFCF..D \\
\hline 78 & Government Consumption Expenditure (real) & 1 & $\mathrm{Q}$ & 1 & 2010Mil€ & 3 & FRCNGOV.D \\
\hline 79 & Total Retail Trade (Value) & 1 & $\mathrm{Q}$ & 1 & $2010=100$ & 3 & FRQSLI07E \\
\hline 80 & Industrial Production (Volume) & 1 & $\mathrm{Q}$ & 1 & $2010=100$ & 3 & FRQ66..CE \\
\hline 81 & Capacity Utilization, Total & 1 & $\mathrm{Q}$ & 1 & $\%$ & 1 & FRCAPUTLQ \\
\hline 82 & Consumer Price Index, All Items & 2 & $\mathrm{Q}$ & 0 & $2010=100$ & 3 & FRQCP009F \\
\hline 83 & Core Consumer Price Index & 2 & $\mathrm{Q}$ & 0 & $2010=100$ & 3 & FRQCP042F \\
\hline 84 & Consumer Price Index, Energy & 2 & $\mathrm{Q}$ & 0 & $2010=100$ & 3 & FRQCP041F \\
\hline 85 & Producer Price Index, Total Industry & 2 & $\mathrm{Q}$ & 0 & $2010=100$ & 3 & FRXPPI..F \\
\hline 86 & GDP Deflator & 2 & $\mathrm{Q}$ & 1 & $2010=100$ & 3 & FRQNA057E \\
\hline 87 & House Price Index & 2 & $\mathrm{Q}$ & 0 & $2010 Q 1=100$ & 3 & FRXPHI..F \\
\hline 88 & Personal Consumption Expenditure (real) & 3 & $\mathrm{Q}$ & 1 & 2010Mil€ & 3 & FRCNPER.D \\
\hline 89 & Personal Disposable Income (real) & 3 & $\mathrm{Q}$ & 0 & $2010 \mathrm{Bil} €$ & 3 & FRXPEDY.C \\
\hline 90 & Hourly Earnings, All Sectors Excluding Agriculture & 3 & $\mathrm{Q}$ & 0 & $2008 \mathrm{M} 12=100$ & 3 & FRWAGES.F \\
\hline 91 & Employment, Total & 4 & $\mathrm{Q}$ & 1 & Thous. & 3 & FREMPTOTO \\
\hline 92 & Unemployment Rate & 4 & $\mathrm{M}$ & 1 & $\%$ & 1 & FRUN\%TOTQ \\
\hline 93 & Unit Wage Costs, Whole Economy & 4 & $\mathrm{Q}$ & 0 & $2008=100$ & 3 & FRXWCU..F \\
\hline 94 & Unit Wage Costs, Manufacturing & 4 & $\mathrm{Q}$ & 0 & $2008=100$ & 3 & FRXWCMF.F \\
\hline 95 & Money Supply M1 & 5 & M & 0 & Bil€ & 3 & FRM1....A \\
\hline 96 & Money Supply M3 (Contribution to Euro Basis) & 5 & M & 0 & $\mathrm{Bil} €$ & 3 & FRM3....A \\
\hline 97 & Policy Rate*: Discount Rate / Short-term Euro Repo Rate & 6 & $\mathrm{M}$ & 0 & $\%$ & 1 & FRPRATE. \\
\hline 98 & Frankfurt Interbank Offered Rate, 3 Month & 6 & M & 0 & $\%$ & 1 & FRINTER3 \\
\hline 99 & Long-term Government Bond Yield & 6 & $\mathrm{M}$ & 0 & $\%$ & 1 & FRGBOND. \\
\hline 100 & SBF 250 Share Price Index & 7 & $\mathrm{M}$ & 0 & $2000=100$ & 3 & FRSHRPRCF \\
\hline 101 & Credit to private nonfinancial sectors from all sectors & 7 & $\mathrm{Q}$ & 0 & Bil€ & 3 & FRBLCAPAA \\
\hline 102 & Cross-border credit positions reported by banking offices & 7 & $\mathrm{Q}$ & 0 & Mil\$ & 3 & \\
\hline 103 & OECD Industrial Confidence Indicator & 7 & $\mathrm{M}$ & 1 & Actual & 3 & FROBS085Q \\
\hline 105 & Composite Leading Indicator & 7 & M & 1 & Actual & 3 & FRCYLEADT \\
\hline 105 & Competitiveness Indicator, Relative Unit Labour Costs & 7 & $\mathrm{Q}$ & 1 & $2010=100$ & 3 & FROCFCDRE \\
\hline 106 & Exports, Goods \& Services, Total (real) & 8 & $\mathrm{Q}$ & 1 & 2010Mil€ & 3 & FREXNGS.D \\
\hline 107 & Imports, Goods \& Services, Total (real) & 8 & $\mathrm{Q}$ & 1 & $2010 \mathrm{Mil} €$ & 3 & FRIMNGS.D \\
\hline 108 & Nominal Exchange Rate: FRF- $€ / \$$ & 8 & $\mathrm{Q}$ & 0 & $€$ & 1 & FRQCC015P \\
\hline 109 & Real Effective Exchange Rate, Consumer Price Index Based & 8 & $\mathrm{Q}$ & 0 & $2010=100$ & 1 & FRQCC011H \\
\hline 110 & Terms Of Trade & 8 & M & 0 & $2005=100$ & 3 & FRTOTPRCF \\
\hline \multicolumn{8}{|c|}{ Netherlands } \\
\hline 111 & GDP (real) & 1 & $\mathrm{Q}$ & 1 & $2010 \mathrm{Mil} €$ & 3 & NLOEXO03D \\
\hline 112 & GFCF (real) & 1 & $\mathrm{Q}$ & 1 & $2010 \mathrm{Mil} €$ & 3 & NLOEXO04D \\
\hline 113 & Government Consumption Expenditure (real) & 1 & $\mathrm{Q}$ & 1 & 2010Bil€ & 3 & NLXGCR..D \\
\hline 114 & Total Retail Trade (Value) & 1 & $\mathrm{Q}$ & 1 & $2010=100$ & 3 & NLQSLI07E \\
\hline 115 & Industrial Production (Volume) & 1 & $\mathrm{Q}$ & 1 & $2010=100$ & 3 & NLQ66..CE \\
\hline 116 & Capacity Utilization, Total & 1 & $\mathrm{Q}$ & 0 & $\%$ & 1 & NLCAPUTLR \\
\hline 117 & Consumer Price Index, All Items & 2 & $\mathrm{M}$ & 0 & $2010=100$ & 3 & NLCONPRCF \\
\hline 118 & Core Consumer Price Index & 2 & $\mathrm{Q}$ & 0 & $2010=100$ & 3 & NLQCP042F \\
\hline 119 & Consumer Price Index, Energy & 2 & $\mathrm{Q}$ & 0 & $2010=100$ & 3 & NLQCP041F \\
\hline 120 & Producer Price Index, Total Industry & 2 & $\mathrm{Q}$ & 0 & $2010=100$ & 3 & NLQPIAT2F \\
\hline 121 & GDP Deflator & 2 & $\mathrm{Q}$ & 1 & $2010=100$ & 3 & NLQNA057E \\
\hline 122 & House Price Index & 2 & $\mathrm{Q}$ & 0 & $2010=100$ & 3 & NLXPHI..F \\
\hline 123 & Personal Consumption Expenditure (real) & 3 & $\mathrm{Q}$ & 1 & 2010 Mil€ & 3 & NLOEXO06D \\
\hline 124 & Personal Disposable Income (real) & 3 & $\mathrm{Q}$ & 0 & 2010Bil€ & 3 & NLXPEDY.C \\
\hline 125 & Hourly Earnings, Manufacturing & 3 & $\mathrm{Q}$ & 1 & $2010=100$ & 3 & NLOLC007E \\
\hline 126 & Employment, Total & 4 & $\mathrm{Q}$ & 1 & Thous. & 3 & NLOCFEMPO \\
\hline 127 & Unemployment Rate & 4 & $\mathrm{Q}$ & 1 & $\%$ & 1 & NLOCFUNRQ \\
\hline 128 & Unit Wage Costs, Whole Economy & 4 & $\mathrm{Q}$ & 0 & $2008=100$ & 3 & NLXWCU..F \\
\hline 129 & Unit Wage Costs, Manufacturing & 4 & $\mathrm{Q}$ & 0 & $2008=100$ & 3 & NLXWCMF.F \\
\hline 130 & Money Supply M1 & 5 & $\mathrm{M}$ & 0 & Bil€ & 3 & NLM1....A \\
\hline 131 & Money Supply M3 (Contribution to Euro Basis) & 5 & M & 0 & Bil€ & 3 & NLM3....A \\
\hline 132 & Policy Rate*: Discount Rate / Short-term Euro Repo Rate & 6 & $\mathrm{M}$ & 0 & $\%$ & 1 & NLPRATE. \\
\hline 133 & Frankfurt Interbank Offered Rate, 3 Month & 6 & M & 0 & $\%$ & 1 & NLINTER3 \\
\hline 134 & Long-term Government Bond Yield & 6 & $\mathrm{M}$ & 0 & $\%$ & 1 & NLGBOND. \\
\hline 135 & Amsterdam SE All Share Stock Price Index & 7 & $\mathrm{M}$ & 0 & $1983=100$ & 3 & NLSHRPRCF \\
\hline 136 & Credit to private nonfinancial sectors from all sectors & 7 & $\mathrm{Q}$ & 0 & Bil€ & 3 & NLBLCAPAA \\
\hline 137 & Cross-border credit positions reported by banking offices & 7 & $\mathrm{Q}$ & 0 & Mil\$ & 3 & \\
\hline 138 & OECD Industrial Confidence Indicator & 7 & $\mathrm{M}$ & 1 & Actual & 3 & NLOBS085Q \\
\hline 139 & Composite Leading Indicator & 7 & $\mathrm{M}$ & 1 & Actual & 3 & NLCYLEADT \\
\hline 140 & Competitiveness Indicator, Relative Unit Labour Costs & 7 & $\mathrm{Q}$ & 1 & $2010=100$ & 3 & NLOCFCDRE \\
\hline 141 & Exports, Goods \& Services, Total (real) & 8 & $\mathrm{Q}$ & 1 & 2010Mil€ & 3 & NLOEXO01D \\
\hline 142 & Imports, Goods \& Services, Total (real) & 8 & $\mathrm{Q}$ & 1 & 2010Mil€ & 3 & NLOEXO05D \\
\hline 143 & Nominal Exchange Rate: Netherlands Guilders- $€ / \$$ & 8 & $\mathrm{Q}$ & 1 & $€$ & 1 & NLQCC015P \\
\hline 144 & Real Effective Exchange Rate, Consumer Price Index Based & 8 & $\mathrm{Q}$ & 0 & $2010=100$ & 1 & NLQCC011H \\
\hline 145 & Terms Of Trade & 8 & M & 0 & $2010=100$ & 3 & NLTOTPRCF \\
\hline
\end{tabular}


Table A.1: Data description and treatment (continued)

\begin{tabular}{|c|c|c|c|c|c|c|c|}
\hline No. & Name & $\mathrm{C}$ & $\mathrm{F}$ & SA & Unit & $\mathrm{T}$ & Series ID \\
\hline \multicolumn{8}{|c|}{ Italy } \\
\hline 146 & GDP (real) & 1 & $\mathrm{Q}$ & 1 & $2010 \mathrm{Mil} €$ & 3 & ITOEXO03D \\
\hline 147 & GFCF (real) & 1 & $\mathrm{Q}$ & 1 & $2010 \mathrm{Mil} €$ & 3 & ITOEXO04D \\
\hline 148 & Government Consumption Expenditure (real) & 1 & $\mathrm{Q}$ & 1 & 2010Bil€ & 3 & ITXGCR..D \\
\hline 149 & Total Retail Trade (Value) & 1 & $\mathrm{Q}$ & 1 & $2010=100$ & 3 & ITXRSVA.E \\
\hline 150 & Industrial Production (Volume) & 1 & $\mathrm{Q}$ & 1 & $2010=100$ & 3 & ITQ66..CE \\
\hline 151 & Capacity Utilization, Manufacturing & 1 & $\mathrm{Q}$ & 1 & $\%$ & 1 & ITOBS076Q \\
\hline 152 & Consumer Price Index, All Items & 2 & $\mathrm{M}$ & 0 & $2010=100$ & 3 & ITCONPRCF \\
\hline 153 & Core Consumer Price Index & 2 & $\mathrm{Q}$ & 0 & $2010=100$ & 3 & ITQCP042F \\
\hline 154 & Consumer Price Index, Energy & 2 & $\mathrm{Q}$ & 0 & $2010=100$ & 3 & ITQCP041F \\
\hline 155 & Producer Price Index, Total Industry & 2 & $\mathrm{Q}$ & 0 & $2010=100$ & 3 & ITXPPI..F \\
\hline 156 & GDP Deflator & 2 & $\mathrm{Q}$ & 1 & $2010=100$ & 3 & ITQNA057E \\
\hline 157 & House Price Index & 2 & $\mathrm{Q}$ & 0 & $1980=100$ & 3 & ITXPHI..F \\
\hline 158 & Personal Consumption Expenditure (real) & 3 & $\mathrm{Q}$ & 1 & $2010 \mathrm{Mil} €$ & 3 & ITOEXO06D \\
\hline 159 & Personal Disposable Income (real) & 3 & $\mathrm{Q}$ & 0 & $2010 \mathrm{Bil} €$ & 3 & ITXPEDY.C \\
\hline 160 & Hourly Earnings, Manufacturing & 3 & $\mathrm{Q}$ & 1 & $2010=100$ & 3 & ITOLC007E \\
\hline 161 & Employment, Total & 4 & $\mathrm{Q}$ & 1 & Thous. & 3 & ITOCFEMPO \\
\hline 162 & Unemployment Rate & 4 & $\mathrm{Q}$ & 1 & $\%$ & 1 & ITOCFUNRQ \\
\hline 163 & Unit Wage Costs, Whole Economy & 4 & $\mathrm{Q}$ & 0 & $2008=100$ & 3 & ITXWCU..F \\
\hline 164 & Unit Wage Costs, Manufacturing & 4 & $\mathrm{Q}$ & 0 & $2008=100$ & 3 & ITXWCMF.F \\
\hline 165 & Money Supply M1 & 5 & M & 0 & Bil€ & 3 & ITM1....A \\
\hline 166 & Money Supply M3 (Contribution to Euro Basis) & 5 & M & 0 & Bil€ & 3 & ITM3....A \\
\hline 167 & Policy Rate*: Discount Rate / Short-term Euro Repo Rate & 6 & M & 0 & $\%$ & 1 & ITPRATE. \\
\hline 168 & Frankfurt Interbank Offered Rate, 3 Month & 6 & M & 0 & $\%$ & 1 & ITINTER3 \\
\hline 169 & Long-term Government Bond Yield & 6 & M & 0 & $\%$ & 1 & ITGBOND. \\
\hline 170 & Milan COMIT General Share Price Index & 7 & M & 0 & $1973 \mathrm{M} 1=100$ & 3 & ITSHRPRCF \\
\hline 171 & Credit to private nonfinancial sectors from all sectors & 7 & $\mathrm{Q}$ & 0 & Bil€ & 3 & ITBLCAPAA \\
\hline 172 & Cross-border credit positions reported by banking offices & 7 & $\mathrm{Q}$ & 0 & Mil\$ & 3 & \\
\hline 173 & OECD Industrial Confidence Indicator & 7 & M & 1 & Actual & 3 & ITOBS085Q \\
\hline 174 & Composite Leading Indicator & 7 & M & 1 & Actual & 3 & ITCYLEADT \\
\hline 175 & Competitiveness Indicator, Relative Unit Labour Costs & 7 & $\mathrm{Q}$ & 1 & $2010=100$ & 3 & ITOCFCDRE \\
\hline 176 & Exports, Goods \& Services, Total (real) & 8 & $\mathrm{Q}$ & 1 & 2010Mil€ & 3 & ITOEXO01D \\
\hline 177 & Imports, Goods \& Services, Total (real) & 8 & $\mathrm{Q}$ & 1 & $2010 \mathrm{Mil} €$ & 3 & ITOEXO05D \\
\hline 178 & Nominal Exchange Rate: ITL- $€ / \$$ & 8 & $\mathrm{Q}$ & 0 & $€$ & 1 & ITQCC015P \\
\hline 179 & Real Effective Exchange Rate, Consumer Price Index Based & 8 & $\mathrm{Q}$ & 0 & $2010=100$ & 1 & ITQCC011H \\
\hline 180 & Terms Of Trade & 8 & M & 0 & $2010=100$ & 3 & ITTOTPRCF \\
\hline \multicolumn{8}{|c|}{ Spain } \\
\hline 181 & GDP (real) & 1 & $\mathrm{Q}$ & 1 & $2010 \mathrm{Mil} €$ & 3 & ESOEXO03D \\
\hline 182 & GFCF (real) & 1 & $\mathrm{Q}$ & 1 & $2010 \mathrm{Mil} €$ & 3 & ESOEXO04D \\
\hline 183 & Government Consumption Expenditure (real) & 1 & $\mathrm{Q}$ & 1 & 2010Mil€ & 3 & ESCNGOV.D \\
\hline 184 & Total Retail Trade (Value) & 1 & $\mathrm{Q}$ & 1 & $2010=100$ & 3 & ESXRSVA.E \\
\hline 185 & Industrial Production (Volume) & 1 & $\mathrm{Q}$ & 1 & $2010=100$ & 3 & ESQ66..CE \\
\hline 186 & Capacity Utilization, Total & 1 & $\mathrm{Q}$ & 0 & $\%$ & 1 & ESCAPUTLR \\
\hline 187 & Consumer Price Index, All Items & 2 & $\mathrm{M}$ & 0 & $2010=100$ & 3 & ESCONPRCF \\
\hline 188 & Core Consumer Price Index & 2 & $\mathrm{Q}$ & 0 & $2010=100$ & 3 & ESQCP042F \\
\hline 189 & Consumer Price Index, Energy & 2 & $\mathrm{Q}$ & 0 & $2010=100$ & 3 & ESQCP041F \\
\hline 190 & Producer Price Index, Total Industry & 2 & $\mathrm{M}$ & 0 & $2010=100$ & 3 & ESPROPRCF \\
\hline 191 & GDP Deflator & 2 & $\mathrm{Q}$ & 1 & $2010=100$ & 3 & ESQNA057E \\
\hline 192 & House Price Index & 2 & $\mathrm{Q}$ & 0 & $2005 \mathrm{Q} 1=100$ & 3 & ESXPHI..F \\
\hline 193 & Personal Consumption Expenditure (real) & 3 & $\mathrm{Q}$ & 1 & 2010Mil€ & 3 & ESOEXO06D \\
\hline 194 & Personal Disposable Income (real) & 3 & $\mathrm{Q}$ & 0 & 2010Bil€ & 3 & ESXPEDY.C \\
\hline 195 & Hourly Earnings, Manufacturing & 3 & $\mathrm{Q}$ & 1 & $2010=100$ & 3 & ESOLC007E \\
\hline 196 & Employment, Total & 4 & $\mathrm{Q}$ & 0 & Thous. & 3 & ESEMPTOTP \\
\hline 197 & Unemployment Rate & 4 & $\mathrm{M}$ & 0 & $\%$ & 1 & ESUN\%TOTR \\
\hline 198 & Unit Wage Costs, Whole Economy & 4 & $\mathrm{Q}$ & 0 & $2008=100$ & 3 & ESXWCU..F \\
\hline 199 & Unit Wage Costs, Manufacturing & 4 & $\mathrm{Q}$ & 0 & $2008=100$ & 3 & ESXWCMF.F \\
\hline 200 & Money Supply M1 & 5 & $\mathrm{M}$ & 0 & Bil€ & 3 & ESM1....A \\
\hline 201 & Money Supply M3 (Contribution to Euro Basis) & 5 & M & 0 & Bil€ & 3 & ESM3....A \\
\hline 202 & Policy Rate*: Discount Rate / Short-term Euro Repo Rate & 6 & M & 0 & $\%$ & 1 & ESPRATE. \\
\hline 203 & Short-term Interest Rate (Average) & 6 & $\mathrm{Q}$ & 1 & $\%$ & 1 & ESOCFISTR \\
\hline 204 & Long-term Government Bond Yield & 6 & $\mathrm{M}$ & 0 & $\%$ & 1 & ESGBOND. \\
\hline 205 & Madrid S E General Index & 7 & $\mathrm{M}$ & 0 & $1985 \mathrm{M} 12=100$ & 3 & ESSHRPRCF \\
\hline 206 & Credit to private nonfinancial sectors from all sectors & 7 & $\mathrm{Q}$ & 0 & Bil€ & 3 & ESLCAPAA \\
\hline 207 & Cross-border credit positions reported by banking offices & 7 & $\mathrm{Q}$ & 0 & Mil\$ & 3 & \\
\hline 208 & OECD Industrial Confidence Indicator & 7 & $\mathrm{M}$ & 1 & Actual & 3 & ESOBS085Q \\
\hline 209 & Composite Leading Indicator & 7 & M & 1 & Actual & 3 & ESCYLEADT \\
\hline 210 & Competitiveness Indicator, Relative Unit Labour Costs & 7 & $\mathrm{Q}$ & 1 & $2010=100$ & 3 & ESOCFCDRE \\
\hline 211 & Exports, Goods \& Services, Total (real) & 8 & $\mathrm{Q}$ & 1 & 2010Mil€ & 3 & ESOEXO01D \\
\hline 212 & Imports, Goods \& Services, Total (real) & 8 & $\mathrm{Q}$ & 1 & $2010 \mathrm{Mil} €$ & 3 & ESOEXO05D \\
\hline 213 & Nominal Exchange Rate: ESP-€/\$ & 8 & $\mathrm{Q}$ & 1 & $€$ & 1 & ESQCC015P \\
\hline 214 & Real Effective Exchange Rate, Consumer Price Index Based & 8 & $\mathrm{Q}$ & 0 & $2010=100$ & 1 & ESQCC011H \\
\hline 215 & Terms Of Trade & 8 & $\mathrm{M}$ & 0 & $2005=100$ & 3 & ESTOTPRCF \\
\hline
\end{tabular}


Table A.1: Data description and treatment (continued)

\begin{tabular}{|c|c|c|c|c|c|c|c|}
\hline No. & Name & $\mathrm{C}$ & $\mathrm{F}$ & SA & Unit & $\mathrm{T}$ & Series ID \\
\hline \multicolumn{8}{|c|}{ Ireland } \\
\hline 216 & GDP (real) & 1 & $\mathrm{Q}$ & 1 & 2010Mil€ & 3 & IROEXO03D \\
\hline 217 & Consumer Price Index, All Items & 2 & $\mathrm{M}$ & 0 & $2011 \mathrm{M} 12=100$ & 3 & IRCONPRCF \\
\hline 218 & Long-term Government Bond Yield & 6 & M & 0 & $\%$ & 1 & IROIR080R \\
\hline \multicolumn{8}{|c|}{ Belgium } \\
\hline 219 & GDP (real) & 1 & $\mathrm{Q}$ & 1 & 2010Mil€ & 3 & BGOEXO03D \\
\hline 220 & Consumer Price Index, All Items & 2 & $\mathrm{M}$ & 0 & $2013=100$ & 3 & BGCONPRCF \\
\hline 221 & Treasury Bill Rate Rate, 3 Month & 6 & M & 0 & $\%$ & 1 & BGINTER3 \\
\hline 222 & Long-term Government Bond Yield & 6 & M & 0 & $\%$ & 1 & BGGBOND. \\
\hline \multicolumn{8}{|c|}{ Finland } \\
\hline 223 & GDP (real) & 1 & $\mathrm{Q}$ & 1 & $2010 \mathrm{Mil} €$ & 3 & FNOEXO03D \\
\hline 224 & Consumer Price Index, All Items & 2 & $\mathrm{M}$ & 0 & $2009=100$ & 3 & FNCONPRCF \\
\hline 225 & Money Market Rate, 3 Month & 6 & M & 0 & $\%$ & 1 & FNI60B.. \\
\hline 226 & Long-term Government Bond Yield & 6 & $\mathrm{Q}$ & 1 & $\%$ & 1 & FNOCFILTR \\
\hline \multicolumn{8}{|c|}{ Portugal } \\
\hline 227 & GDP (real) & 1 & $\mathrm{Q}$ & 1 & $2010 \mathrm{Mil} €$ & 3 & PTOEXO03D \\
\hline 228 & Consumer Price Index, All Items & 2 & M & 0 & $2012=100$ & 3 & PTCONPRCF \\
\hline 229 & Short-term Interest Rate (Average) & 6 & $\mathrm{Q}$ & 1 & $\%$ & 1 & PTOCFISTR \\
\hline 230 & Long-term Government Bond Yield & 6 & $\mathrm{Q}$ & 1 & $\%$ & 1 & PTOCFILTR \\
\hline \multicolumn{8}{|c|}{ EA Aggregates } \\
\hline 231 & GDP (real) & 1 & $\mathrm{Q}$ & 1 & 2010Bil€ & 3 & EKXGDPR.D \\
\hline 232 & Industrial Production (Volume) & 1 & $\mathrm{Q}$ & 1 & $2010=100$ & 3 & EKXIPI..E \\
\hline 233 & GFCF (real) & 1 & $\mathrm{Q}$ & 1 & 2010Bil€ & 3 & EKXIFR..D \\
\hline 234 & Consumer Price Index, All Items & 2 & $\mathrm{Q}$ & 0 & $2005=100$ & 3 & EKXCPI..F \\
\hline 235 & Producer Price Index, Total Industry & 2 & $\mathrm{Q}$ & 0 & $2010=100$ & 3 & EKXPPI..F \\
\hline 236 & GDP Deflator & 2 & $\mathrm{Q}$ & 0 & $2010=100$ & 3 & EKXPGDP.F \\
\hline 237 & Private Consumption Expenditure (real) & 3 & $\mathrm{Q}$ & 1 & 2010Bil€ & 3 & EKXCPR..D \\
\hline 238 & Long-term Government Bond Yield & 6 & $\mathrm{Q}$ & 0 & $\%$ & 1 & EKXRLG..R \\
\hline 239 & Real Effective Exchange Rate, Consumer Price Index Based & 8 & $\mathrm{Q}$ & 0 & $1995=100$ & 1 & EKXRXE..F \\
\hline 240 & Exports, Goods \& Services, Total (real) & 8 & $\mathrm{Q}$ & 1 & 2010Bil€ & 3 & EKXXTR..D \\
\hline 241 & Imports, Goods \& Services, Total (real) & 8 & $\mathrm{Q}$ & 1 & 2010Bil€ & 3 & EKXMTR..D \\
\hline \multicolumn{8}{|c|}{ World Aggregates } \\
\hline 242 & GDP (real) & 1 & $\mathrm{Q}$ & 1 & 2010MilUS\$ & 3 & WDXGDPR.D \\
\hline 243 & Consumer Price Index, All Items & 2 & $\mathrm{Q}$ & 0 & $2000=100$ & 3 & WDXCPI..F \\
\hline 244 & World Commodity Prices: Crude Oil & 2 & $\mathrm{Q}$ & 0 & $2010=100$ & 3 & WDQ76AADF \\
\hline \multicolumn{8}{|c|}{$\begin{array}{l}\text { Note: Outliers are defined as observations exceeding the value } 5 \text { after the standardization procedure. They are replaced with the mean of the } \\
\text { series. All time series are taken from the Thomson Reuters Datastream database except data for (i) cross-border credit which is collected from } \\
\text { the BIS Locational Banking Statistics Database Table } 6 \text { (External Positions of Reporting Banks vis-a-vis Individual Countries); (ii) St. Louis } \\
\text { Adjusted Reserves and the US 1-Year Treasury Constant Maturity Rate which is collected from the FRED Economic Database; (iii) the US ex- } \\
\text { cess bond premium and credit spread which are downloaded from Simon Gilchrists' homepage (http://people.bu.edu/sgilchri/Data/data.htm); } \\
\text { (iv) the US mortgage bond premium which is constructed as the 30-year mortgage rate minus the 10-year Treasury rate. Series not available } \\
\text { with seasonal adjustment are manually adjusted using the X-13-ARIMA procedure (except for interest rates and exchange rates). The Policy } \\
\text { Rate* incorporates the shadow rate as proposed by Wu and Xia (2016). } \\
\text { Categories: } \\
1: \text { national accounts, } 2: \text { prices, } 3: \text { income \& consumption, } 4: \text { labor market, } 5: \text { monetary aggregates, } 6: \text { interest rates, } 7: \text { financial markets \& } \\
\text { business conditions, } 8: \text { foreign exchange market } \\
\text { Abbreviations: } \\
\text { Category ('C'): } 1-8 \\
\text { Frequency ('F'): Q Q Quarterly, M M Monthly } \\
\text { Transformations ('T'): } 1=\text { none, } 3=\text { first difference of natural logarithm, } 5=\text { natural logarithm } \\
\text { Seasonal adjustment ('SA'): } 0=\text { no, } 1=\text { yes }\end{array}$} \\
\hline
\end{tabular}




\section{B Results from the robustness checks}
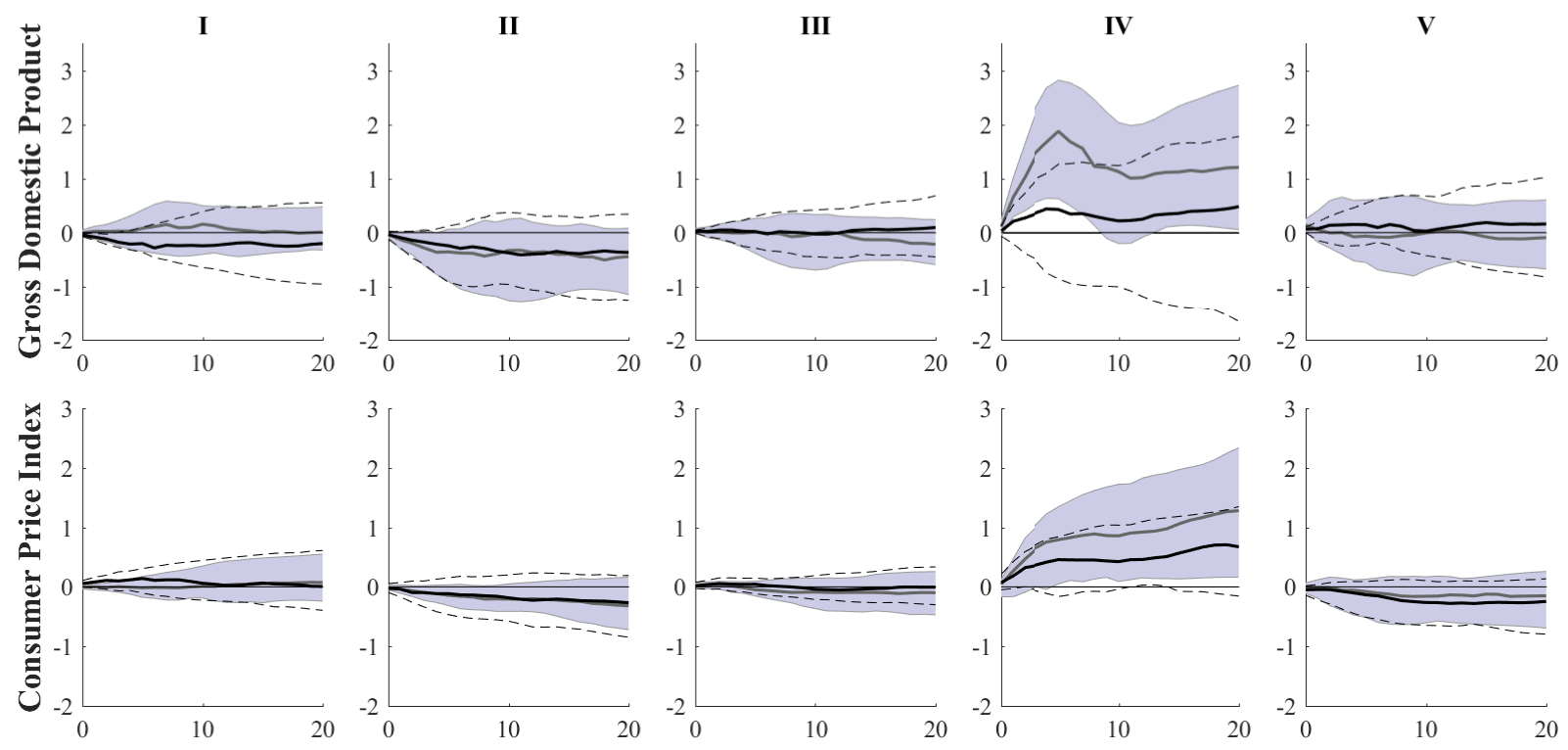

Figure B.1: Testing model asymmetries: variations on the identification scheme.

Solid grey lines indicate the estimated median difference to the aggregate EA-wide response of the same variable for the 1983.I-1998.IV period with $84 \%$ confidence bands (dark shaded areas). Solid black lines indicate the estimated median difference to the aggregate EA-wide response of the same variable for the 1999.I-2015.I period with $84 \%$ confidence bands (dashed lines). 

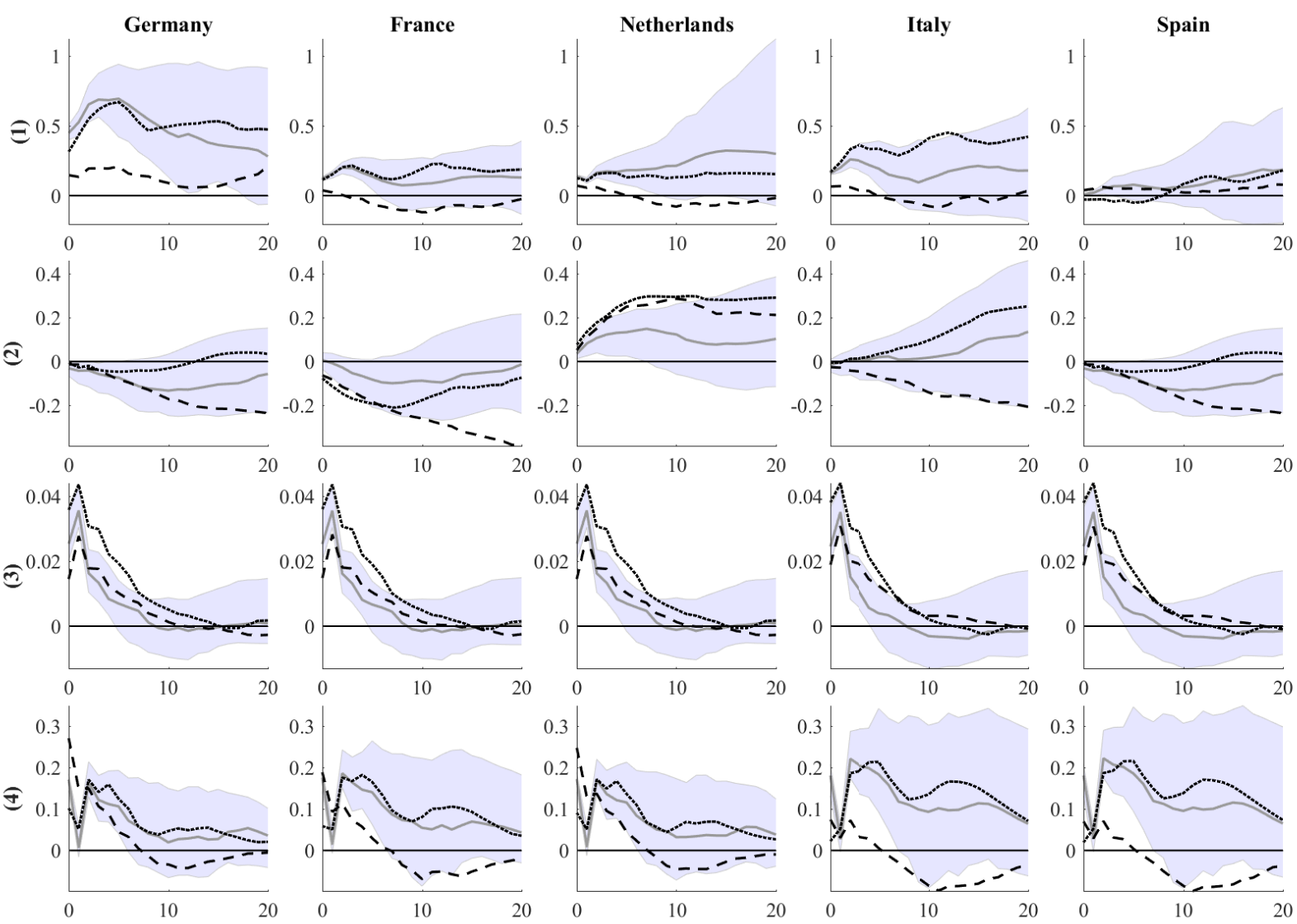

Figure B.2: Impulse responses to a contractionary US monetary policy shock: EA (1) Gross Domestic Product (in \%); (2) Consumer Price Index (in \%); (3) Nominal Exchange Rate (in $€ / \$$ ); (4) Policy Interest Rate (in \%).

Dotted black lines indicate the estimated median reduced-sample impulse responses for the 1999.I-2012.I period. Dashed black lines indicate the estimated median reduced-sample impulse responses for the 1999.I-2008.III period. Solid grey lines indicate the estimated median benchmark impulse responses for the 1999.I-2015.I period with $84 \%$ confidence bands (shaded areas). 